WIID

FIIOWERS. 

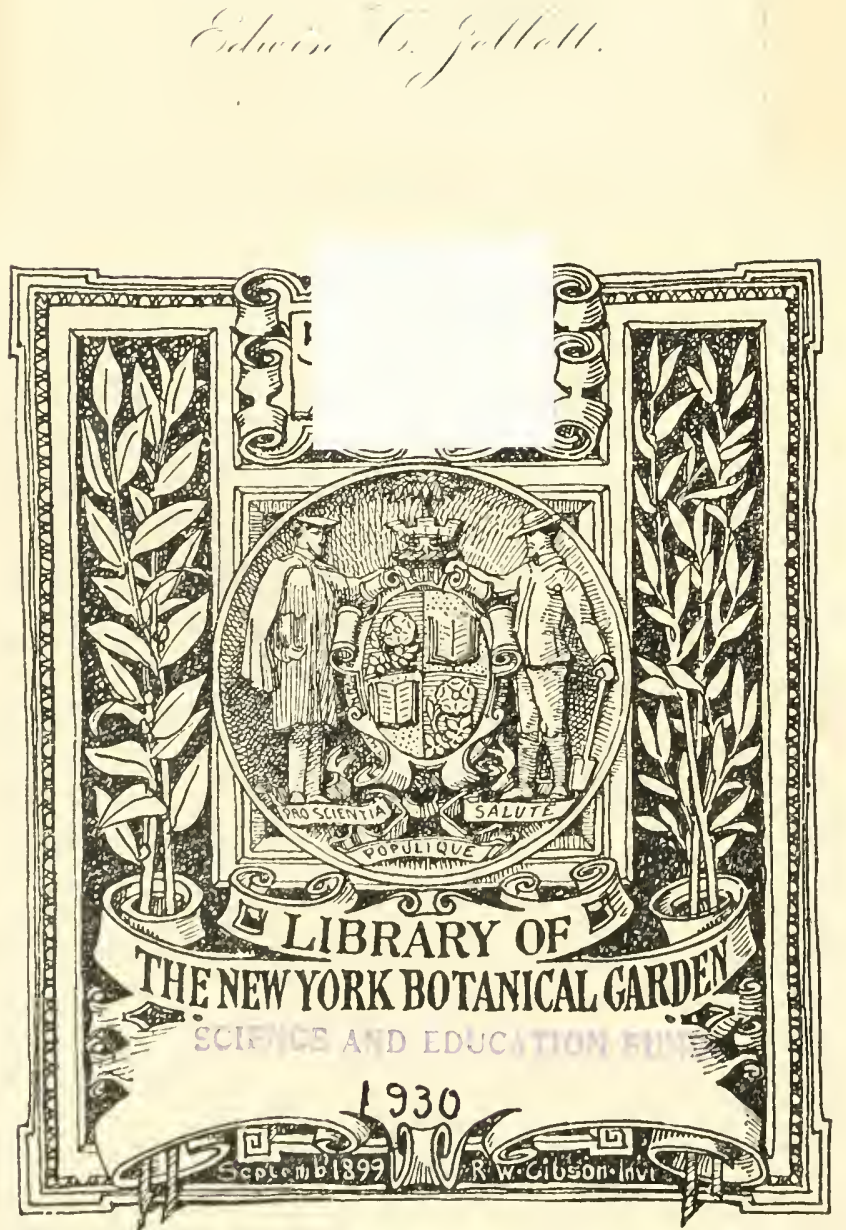
Edwrix. O. frlbett.

Complainento fra. Ar. Heacusfirte 





\title{
CONTRIBUTIONS
}

\author{
TO THE
}

Flora of Beaver County,

FROM THE

\section{MANSFIELD HERBARIUM,}

1865-1903.

BY IRA F, MANSFIELD,

Member of American Philosophical Society and A. A. A. S. 
"Herbarinm! Herbarium, Who zerote it?

No, I never read Herbarim.

Then you haze an immense pleasure to come." 



\section{$P R E F A C E$.}

\section{8}

In preparing this check list it has been based upon a collection of wild flowers found within the county of Beaver, and for thirty-seven years many varieties have been carefully studied to prove they are indigenous to this locality. Although botany is taught quite generally in the various schools of our county, yet with few exceptions, little or no attention is given to the systematic prepartion or preservation of native wild flowers. In carrying on the search and preparing herbarium, careful study has been made of geographical distribution, fertilization, and development. To assist teachers, young naturalists, and those who would like a botany in plain English; the list drops the orders, retaining t!le genera, with names of species in Latin. The object of this check list has been to localize the flora; giving a record of the anthor's own experiences, aided by careful references to the standard works, giving priority to old names; using Gray's botany in all disputed points. I am under obligations to Prof. Leo. Lesquereux, late of Columbus. Ohio, in naming many of the flora, ferns and mosses; Mrs. Lois H. Mansfield, Mrs. Mary K. Mooly, Mrs. Olive C. Beauchamp and parties of lady school teachers, who have camped with me along the Ohio and Beaver rivers; all assisting in discovering and naming new species: also studying the problems as to nativity and objects of 
life of all of our wild flowers. The influence of climate as to plants is plainly shown in our county. The Ohio river, with its low altitude, and mild influences, gives us many flowers that range through our southern states, even to Carolina and Georgia; while the high ranges of hills, with altitudes of I300 feet, along Little Beaver river, with its colder climate, make the flora in many respects like that of the Lake region and Canada. Our entire county is covered with drift of shales and boulders from the ice age, alternating sands, clays and gravels, and the flora of any township depends chiefly on which of these soils happen to lie uppermost. Bordering the streams in every township, the hemlock spruce is abundant, and amid their gloomy recesses are found the club mosses, parasites, the handsome pink ladies' slippers Cypripediums, the Aspleniums and Phegopteris ferns in abundance. Along the low valleys and in the peat bogs of Pine swamp above New Gallilee, grow many varieties of Habenarias, with other orchids: also the three royal Osmunda ferns, with fronds six feet high. Each year there is less opportunity for collecting, the lumberman with his portable saw mill, moves on to fresh spoils, leaving behind an inextricably confused mass of tree tops, broken logs and upturned stumps. The best part of botany after all is not in the books, and to any who find the study dry, we comment camping ont with nature herself; that boundless outdoor life, whose interest, beanty and mystery is with us from the cradle to the grave, forever stimulating inquiry, and ever ichly rewarding patient and loving toil.

Beaver, Pa.. Jantiary ist, Iyo3. 


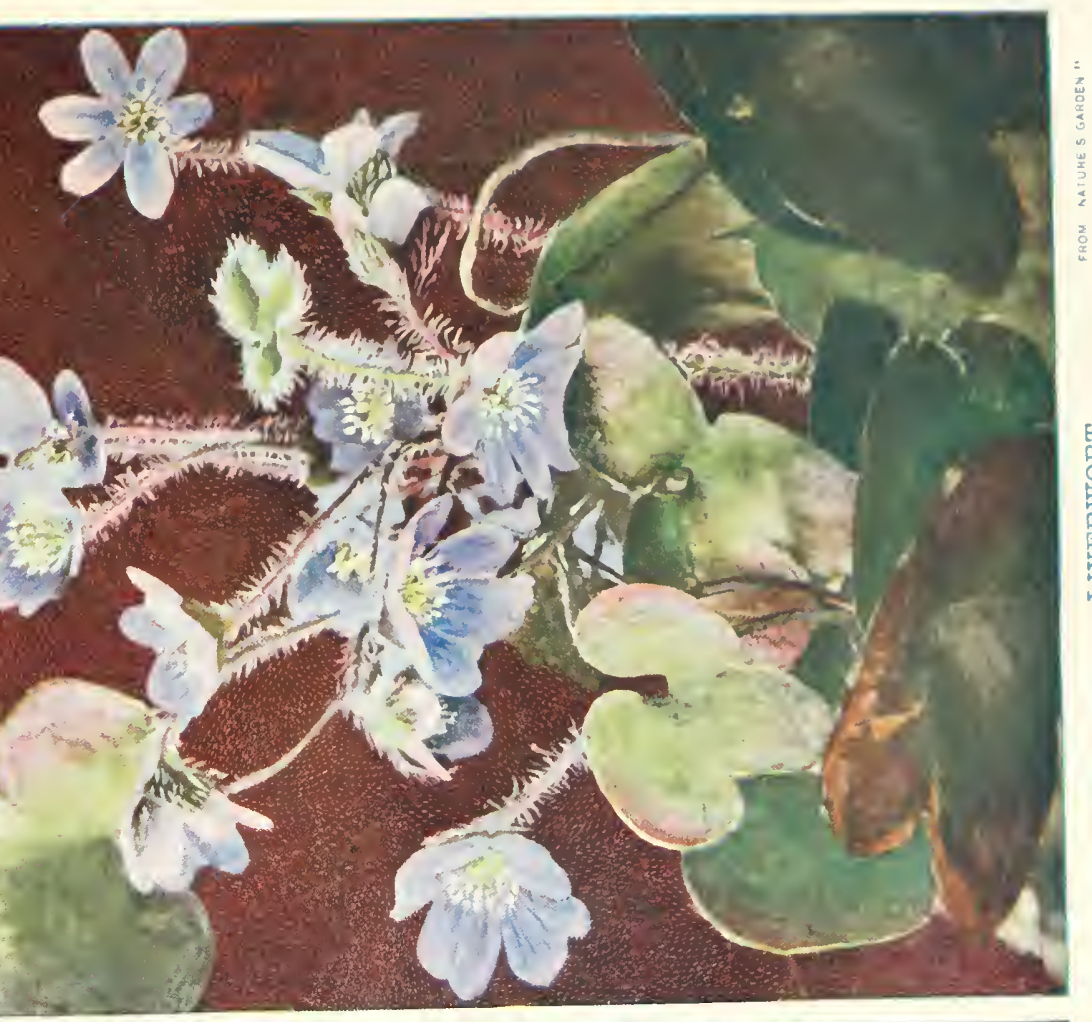

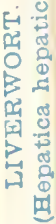

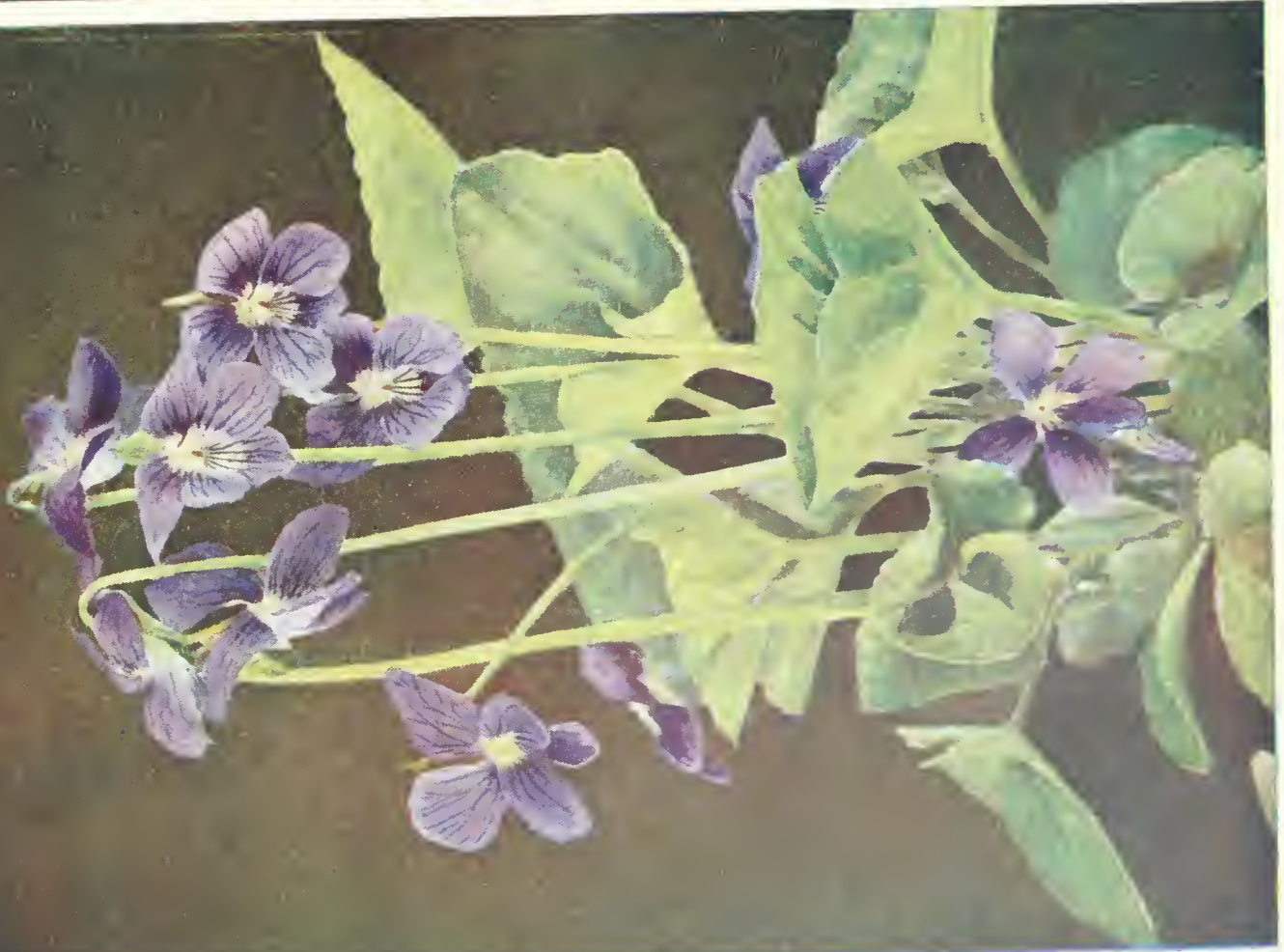





\section{CHECKLIST.}

\section{8}

ACORUS,

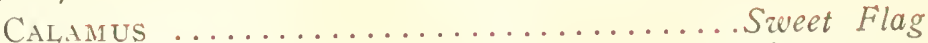

Pungent and aromatic, especially its thick creeping root-stalk which forms the officinal calamus aromaticus. This is now sparingly lised as a stomatic, also in confections, distilling and brewing. Small bees and the Antiopa butterfly may be included as among the frequent early visitors.

ACTOEA,

ALBA ...................White Bancberry

RUBRA

Red Baneberry'

ACTINOMERIS,

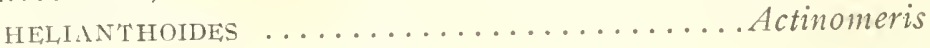

ACHILLEA,

MILLEFOLIUM .................... Yarrow

Tradition claims this plant used by Achilles

to cure the wo:nds of his soldiers and the

genus is nameil for that mighty hero. The

scottish highlanders claim its value in an ointment; the Swedes use it as a substitute for lops in beer, and the Swiss from it make the celebrated Alpine rinegar.

\section{ABUTILON,}

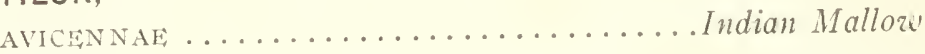

ADIANTUM,

PEDATUM ............................ Hair Fern

AMARYLLIS,

HYPOXIS

Yellow Star Grass

AGRIMONIA,

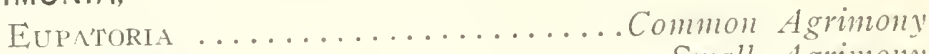

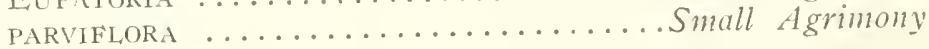




\section{AGROSTIS,}

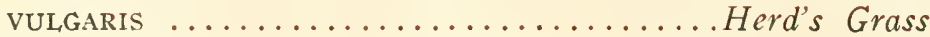

\section{ALLIUM,}

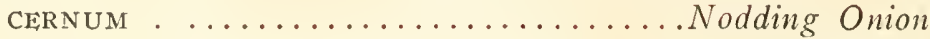

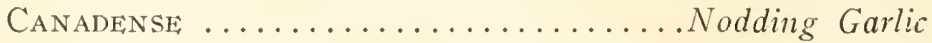

\section{AMPELOPSIS,}

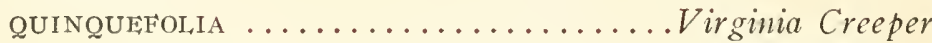

\section{AMPHICARPOEA,}

Monorca .......................... Hog-pea-mut

A graceful vine, bearing two sets of flowers and fruit. The upper flowers are delicate lilac, in drooping clusters; the subterranean ones without petals yielding fruit. The lower ones are fertilized by ants.

\section{ANEMONE,}

Pennsylvanica ....................Thimble Weed

Virginiana ........................ Thimble Weed

Thalictroides ..................Wind Filozer

Nemerosa .......................... Find Finer

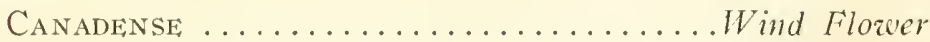

Early and quite showy, the flowers are quite often bright rose color. Fertilized by bees and the small flies Syrphido. The fruit heads of the two first gives the common name.

\section{ANTENNARIA,}

MaRgaritacea .................. Everlasting APLECTRUM-ORCHIS,

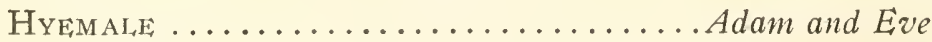





\section{APOCYNUM,}

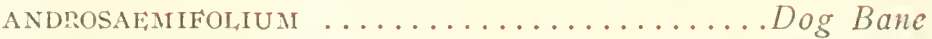

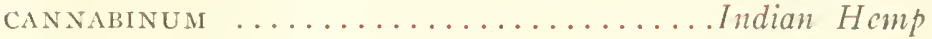

APHYLLON,

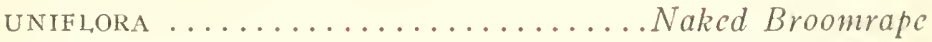

Parasitic with slender one-flowered scapes, often called cancer root. The flowers have yellow folds in the throat and fragrant. The plant yields a bitter juice that is used as a tonic. Cross fertilned by bees and flies.

AQUILEGIA,

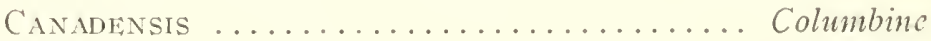

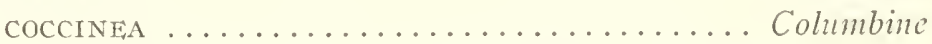

The last species is quite distinct with larger flowers and short spurs, is found growing on south banks of Ohio river. The bird like claws of the blossoms ftrmishes the name. Largely visited at night by the moths and millers.

ARETHUSA-ORCHIS,

BLISOSA . Nymph of Diana

ARABIS,

HESPEKIODES ............................ Cress

HIRSUTA ............................. Cress

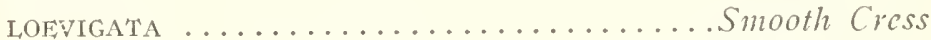

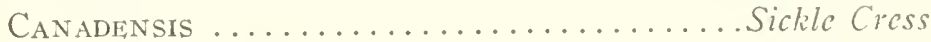

\section{ARISTOLOCHIA,}

SERPENTARIA ............................. Root

ARTEMISIA,

ABSINTHIUM

Wormwood 
ARALIA,

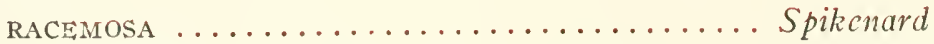

NUdICAULIS $\ldots \ldots \ldots \ldots \ldots \ldots$ Sarsaparilla

TRIFOLIA ............................ Ginseng

QUINQUEFHOLIA $\ldots \ldots \ldots \ldots \ldots \ldots \ldots \ldots$ Ginseng

HISPIDA $\ldots \ldots \ldots \ldots \ldots$ Wild Elder

\section{ARISOEMA,}

TRIPHYLLUM ............................. in the Pulpit

Dracontium ........................ Dragon

The difference in color with the triphyllum i:dicates the sex, the purple stripe spathe the "Lords" and the light green the "Ladies." The law regulating the sex in flowers has always had an interest and the ultimate conclusions are that in the earlier embryonic stages it is not determined, as the leaf bud may in all plants be sither male or female. This is determined by the amount of nutrition the embryo is able to draw unto itself. In dracontium the leaves are grotesquely formed and resemble the claws and foot of a dragon. The long spadix tapering to a long pointbeyond the spathe for the purpose of attracting attention.

ASARUM,

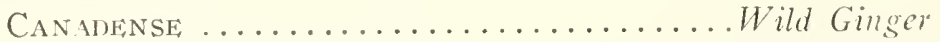

The root has an aromatic odor and a warm, pungent taste. The odd flowers are borne close to the ground, ofien covered with leaves. A few butterflies, but mostly gnats and flies look after distributing the pollen.

ASCLEPIAS,

Cornuti $\ldots \ldots \ldots \ldots \ldots \ldots \ldots . \ldots \ldots$ Silk Weed

QUADRIFOIA $\ldots \ldots \ldots \ldots \ldots \ldots \ldots \ldots \ldots \ldots$ Silk We Wed

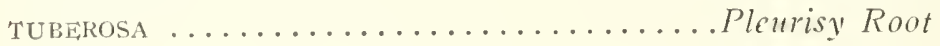



ASTERS,

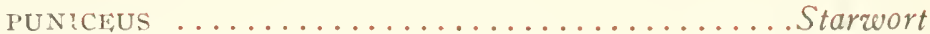

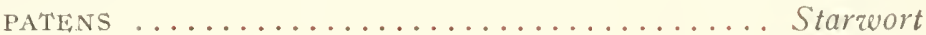

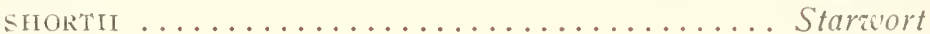

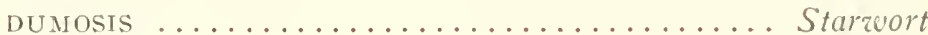

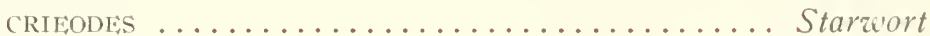

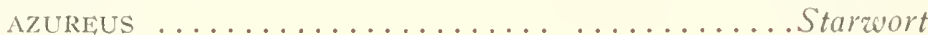

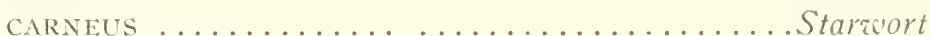

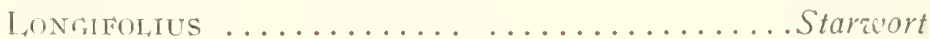

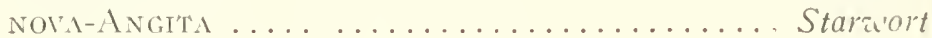

ASPIDIUM,

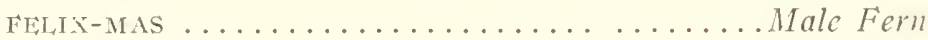

THHLYPTERIS ................... Lady Ficrn

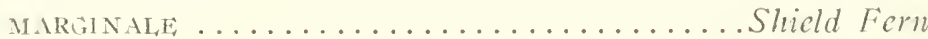

Bootil .....................Wood Fern

Novaboracense ..................... Yew York Fern

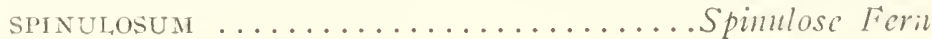

ACROSTICHOIDES ..................Dagger Fern

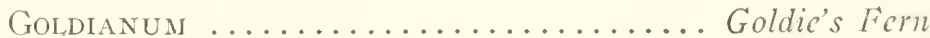

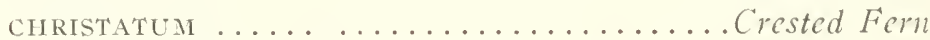

From recent researches the theory that in arowing ferns from the seed spores, that there is a missing link, or in other words that ferns have a grandfather, but no father, has been disproved. The spores of all cryptogamous plants are the samic in purpose and as perfect in use as the seed of other flowering plants. The spores have their antheridia and archegonia or male and female organs, and sometimes are on different prothalli, or at least, not perfected at the same time, on the same one.

\section{ASPLENIUM,}

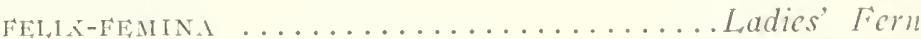
TRICHOMANES ........................... Splenarort

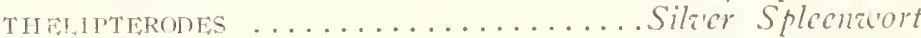
EBENEUN1.................Ebony Splemint

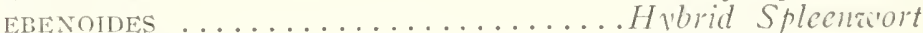

The last named is a hybricl by nature from

A-ebenemm and C-rlizophyllis, the result of one 
species being fertilized by the antheroides of another species. If hybridity among ferns be admitted, then A-Bootii is another hybrid form A-christatum.

AZALEA,

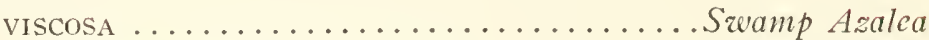

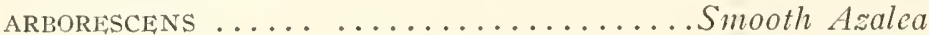

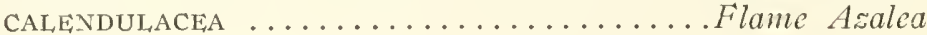

AZOLLA,

Caroliniana $\ldots \ldots \ldots \ldots \ldots \ldots \ldots \ldots \ldots \ldots$. $\ldots \ldots \ldots$

\section{BAPTISIA,}

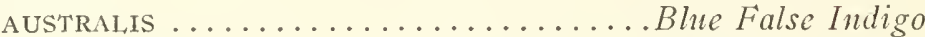

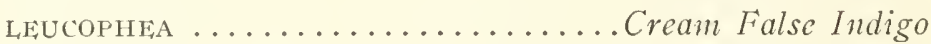

TINCTORIA ......................... Indigo

The plants are common, assigned as a native, liaving been found in every part of the United States. Also cultivated in gardens and used for dyeing, but is a poor substitute. The root in medicine is used as a laxative and in larger doses as a cathartic and emetic. Bees and butterflies constant visitors.

BELLIS,

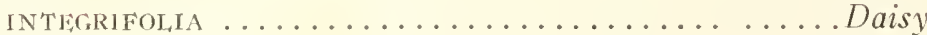

BIDENS,

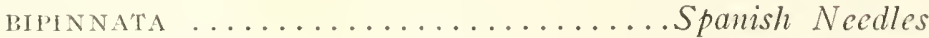

CHRUSANTHEMOIDES ................... Marrigold

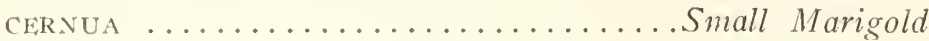

BLEPHILIA,

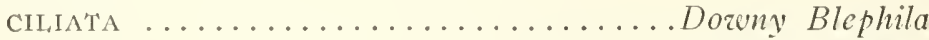

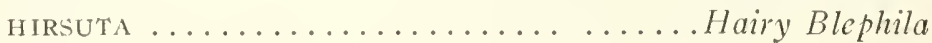



BOTRYCHIUM,

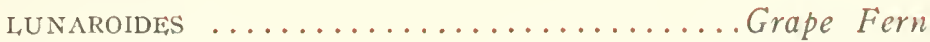

VIRGINICUM ...................Rattlesnake Fern

NEGLECTUM ....................Moonwort

EUCHNERA,

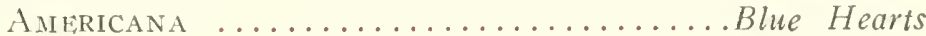

BRUNELLA,

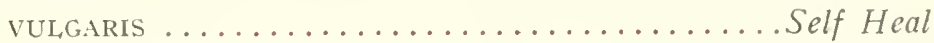

BROMUS,

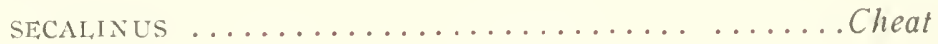

CACALIA,

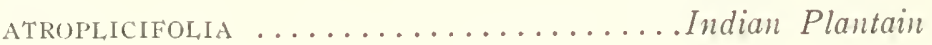

CALYSTEGIA,

SEPIUM ................................. Beanty

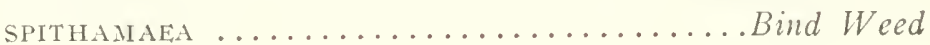

\section{CALTHA,}

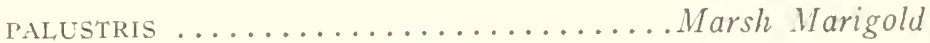

"The marigold that goes to bed with the sun,

And with him rises weeping."

Extensively used by boiling as a vegetable, as a pot herb like spinach. So abundant is the bloom in Johnson's swamp near Cannelton, that the swamp seems paved with gold. The flowers are rich in nectar and the rellow Syrphidoe flies, with the Papilio butterflies look after cross fertilization.

\section{CAMPANULA,}

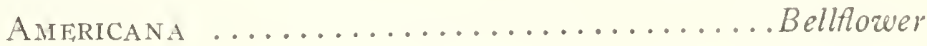


CASSIA,

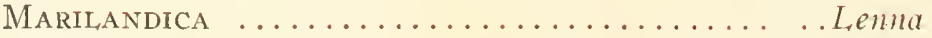

OBTUSIFOLIA .......................... Lenna

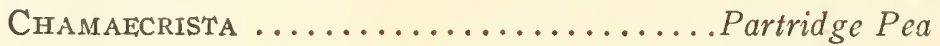

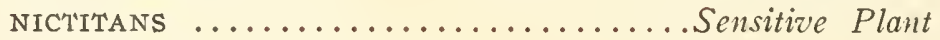

CANNABIS,

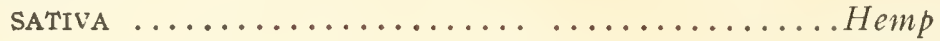

CAMPTOSORUS,

RHIZOPHYLLUS ...............Walking Fern

The venation is peculiar and the disposition of the sori depends on the reticulated veins forming crooked lines and fruit dots. The leaves are prolonged like a rumner, which often roots at the apex, and these in turn to others; hence the popular name.

CARDUUS,

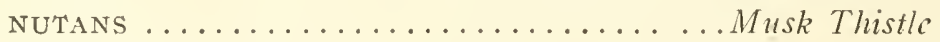

CARDAMINE,

HIRSUTA ............................ Cress

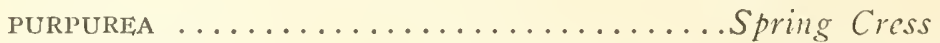

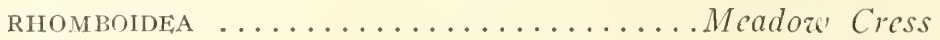

CELASTRUS,

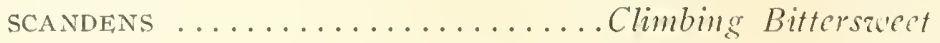

CEANOTHUS,

Americanus .............................. Tea

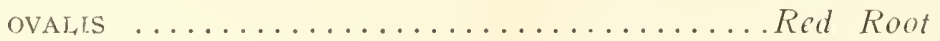

The leaves were used for tea diring the American Revolution, and is still used by some, they claiming that the action is as stimulating as Chinese teas. The flower spikes are slightly fragrant and are visited by many kinds of insects. 


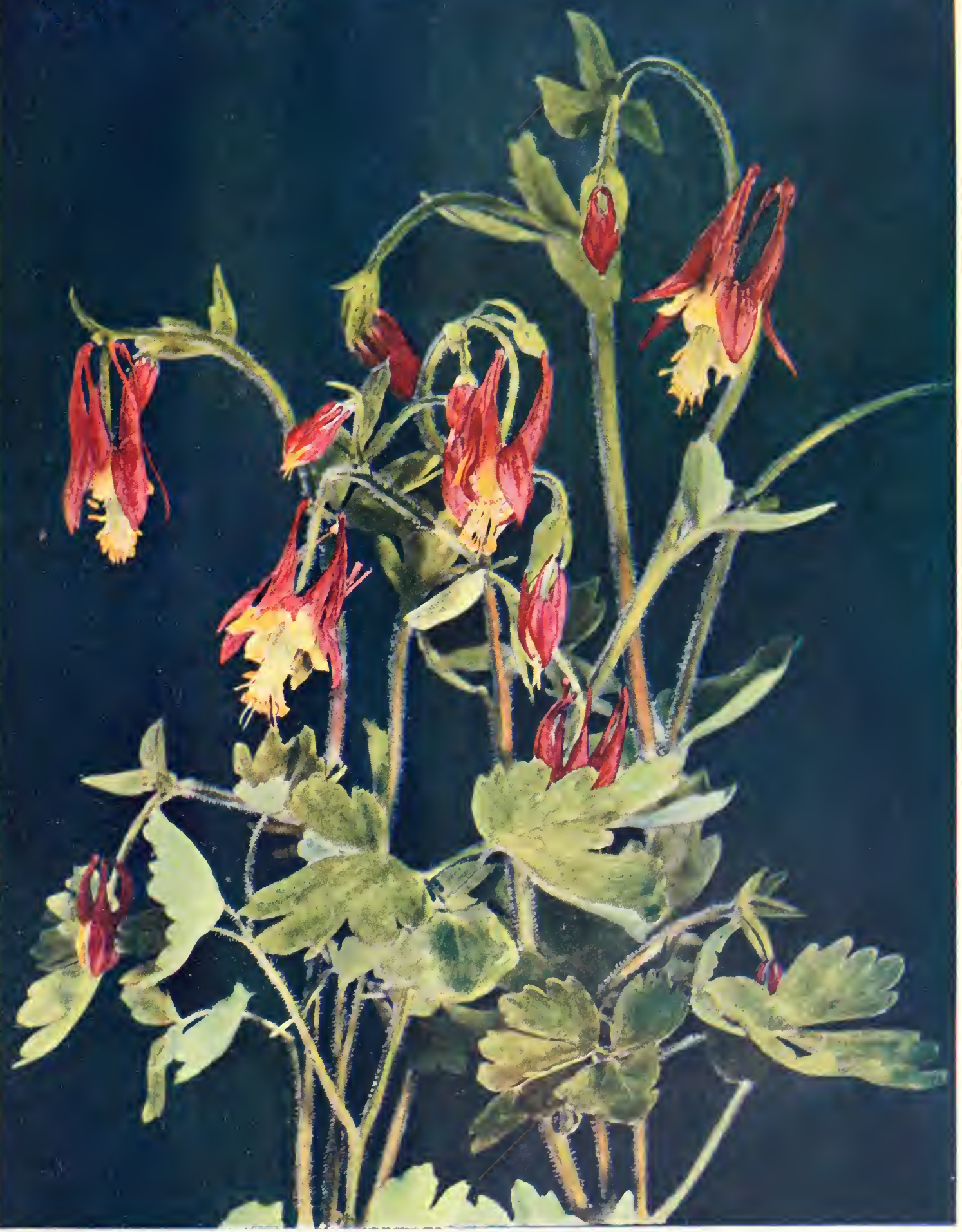




\section{CHELONE,}

GLABRA .............................. Head

\section{CHELIDONIUM,}

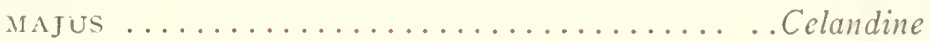

\section{CHRYSOSPLENIUM,}

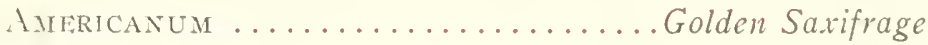

\section{CHIMAPHILA,}

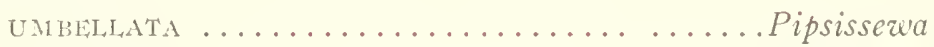

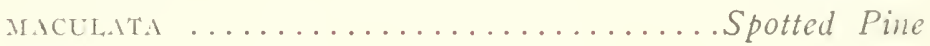

\section{CIRSIUM,}

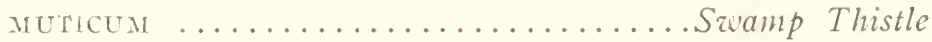

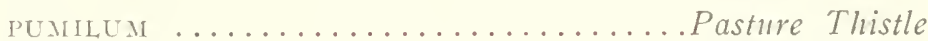

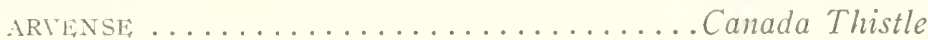

Cylindrical heads with purple flowers, dispensing their seeds by the aid of a light globe of pappus. Linnets, gold-finches and other birds feed on the seeds: and the larva of the plume moth Pterophorus. with the painted lady butterfly Vanessa, largely live on thistle heads. The flowers are fragrant and rich in nectar, which insects imbibe to abject intoxication.

CIMICIFUGA,

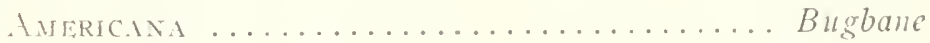

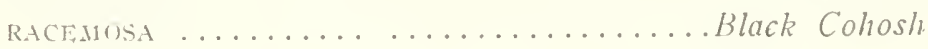
CICUTA,

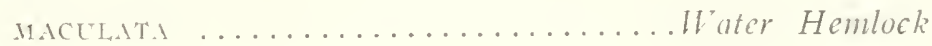
CIRCIA,

LUTETIANA .............Enchanter's Nightshade 


\section{CLEMATIS,}

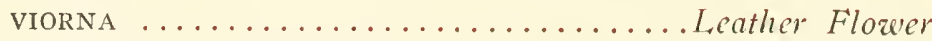

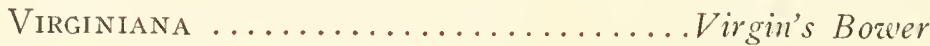

\section{CLINTONIA,}

BORLALIS .................... I' ellow Clintonia

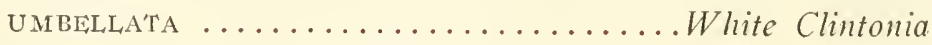

\section{CLAYTONIA,}

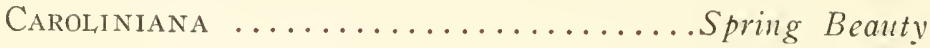

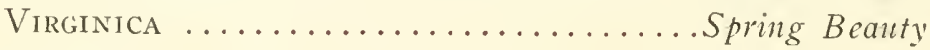

CLEOME,

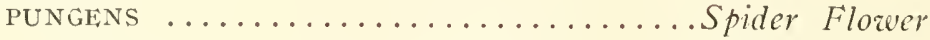

COMMELYYNA,

Virginica ........................... Flozver

CORALLORHIZA-ORCHIS,

ODONTORHIZA ........................... Root

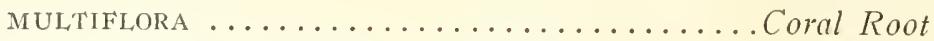

Prized by chemists, but disappointing to orchid hunters. Simple scafe, with sheaths in place of leaves, dull colored red flowers. Its clustered coral roots speak its praises.

COLLINSONIA,

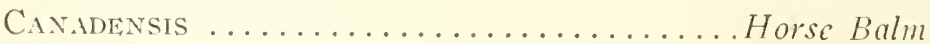

COLINSIA,

VERNIA ....................Innocence

PARTIELTRA ........................ Elle Eyes

CORYDALIS,

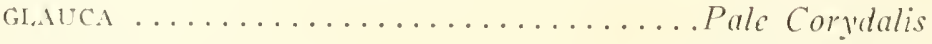

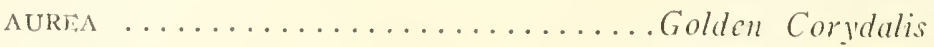

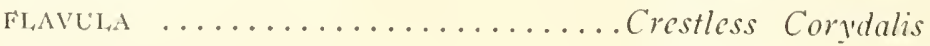




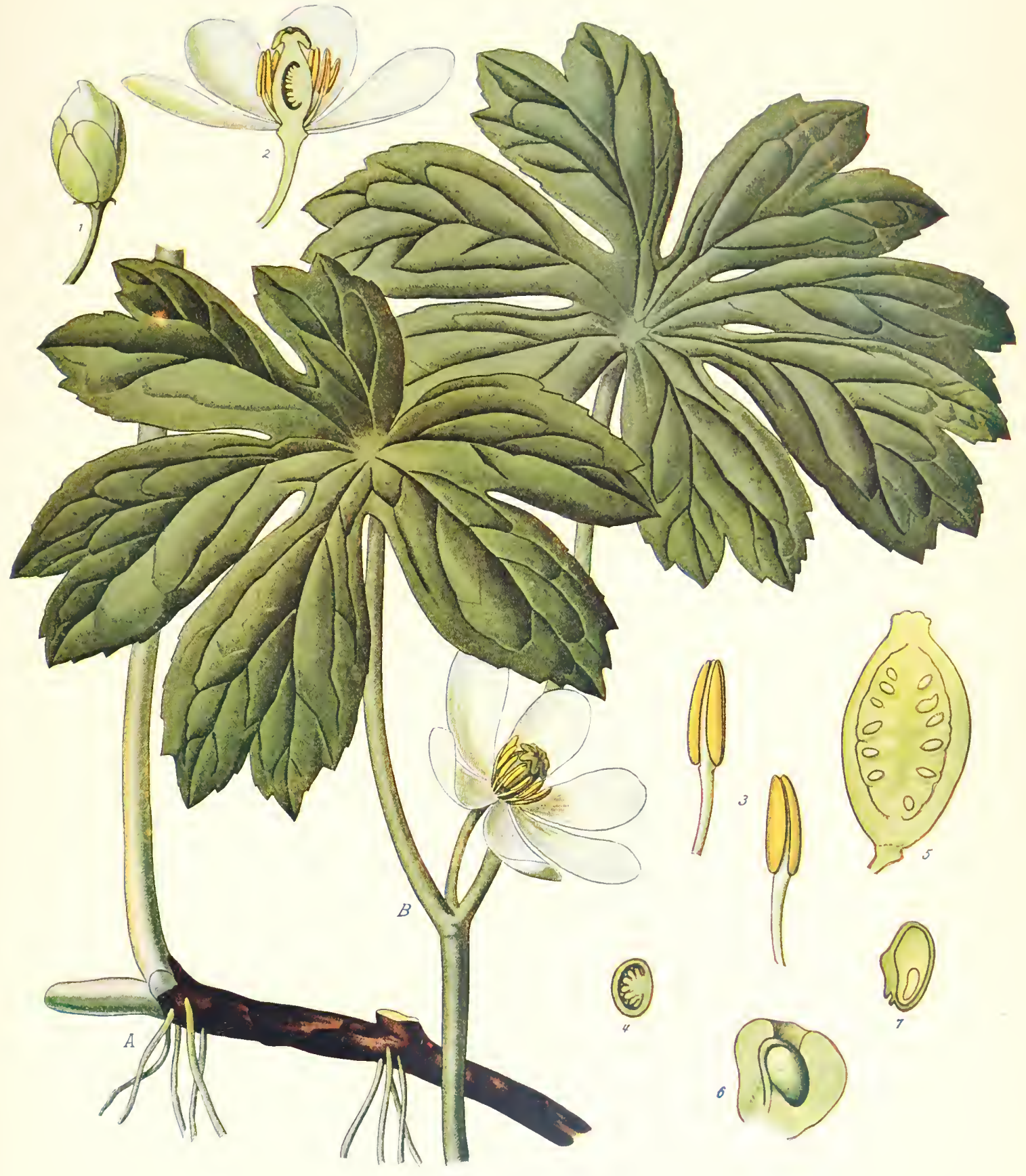



COSMANTHES-P

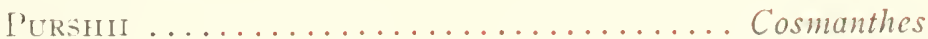

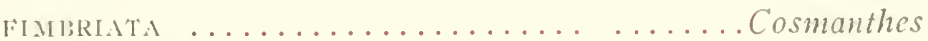

CONOPHOLIS,

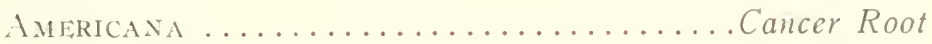

A singular parasite growing in clusters of three

on the roots of oak trees. The upper scales forming bracts to the yellow flowers, while the lower scales covering each other in regular rircler, not unlike those of a fir-cone.

CRYPTOTAENIA,

Canadensis .............................

\section{CUPHEA,}

riscosissina .....................my Cuphea

CUNILA,

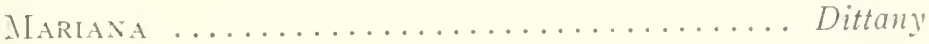

CUSCUTA,

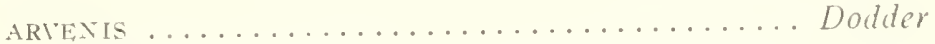

Twining parasites of bad reputation, absolutely without conscience and of uncanny ways, living by sucking the life out of composites. Small flies visit the clusters of tiny white flowers.

CYSTOPTERIS,

IFR.IGILIS Cliff Fern BULPIFERA Bladder Fern

The last named has bulbs scattered at base of pinnaes, which drop to the ground, send ('ut rootlets and send up developed fronds the second season. 


\section{CYNOGLOSSUM,}

OFFICINALS ............................ Tongue

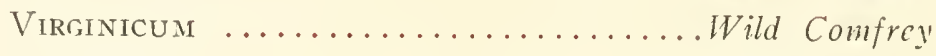

Morisoni .................................. Lice

\section{CYPRIPEDIUM-ORCHIS,}

CANDIDUM ........................ Whate Slipper

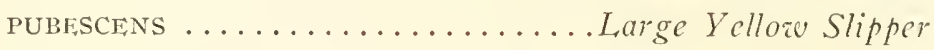

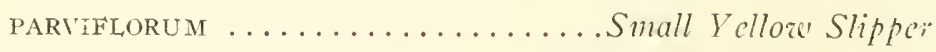

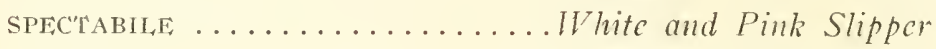

ACAULE ....................Rose-purple Slipper

Orchids are the gypsies of the plant world, being found in every country. They have a geographical movement, a real traveling by new tubes forming on the farther side of each present plant. The flowers often showy, being the only class of plants that show development. Only a few are capable of self-fertilization. They are distinguished from other flowers by a twist in the ovary, having the upper petal brought down, taking the place of the lower petal. In the above species the lip is inflated resembling a Lady's Slipper; others take on forms of insects. Sone botanists claim these changing forms are inherited, but later authorities who have made orchids a study, show that these modifications are associated with the structure and habits of insects and their visits to these flowers. The early Algonquins called them "Indian's mawcahsin flower." Linnaeus in 1740 named this group for Cypris the "Divine Mother" of the Roman people. All these species are visited by bumblebees carrying the pollen on their backs 


$$
8
$$





\section{DATURA,}

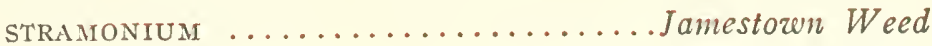

\section{DASYSTOMA,}

FLAVA Foxglove

\section{DALEA,}

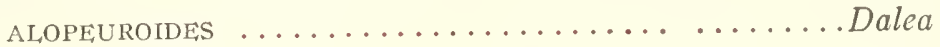

\section{DESMODIUM,}

ACuminatum .............................. Trefoil

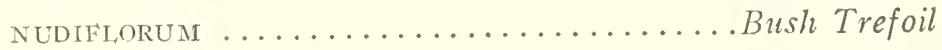

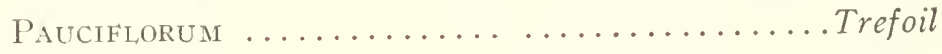

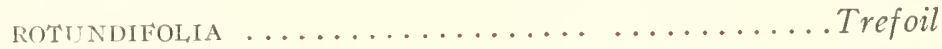

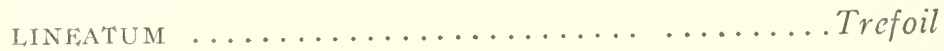

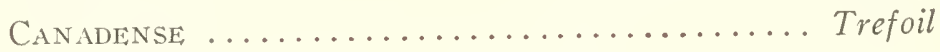

The seeds form a chevaux-de-frise of beggar ticks. Thoreau writes: "Though you were rumning for your life, they would have time to catch and cling to your clothes," and so the seeds get what they wanted, deposited in a new place. Butterflies are frequent visitors.

\section{DELFHINIUM,}

TRIORNE

Larkspur

EXAITUM - Larkspur

AZUREUM

DECODON-N

VERTITILLATUS Loosestrife

Stems reroot themselves from their tips whenever they touch the water. Flowers trimorphous, and only fertilized from a stamen of equal length in another flower. 


\section{DENTARIA,}

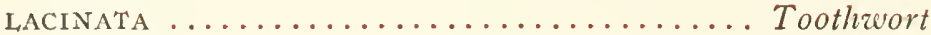

MAXIMA $\ldots \ldots \ldots \ldots \ldots \ldots \ldots$ Toothwort

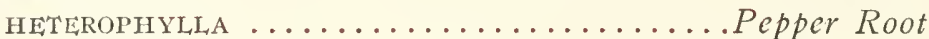

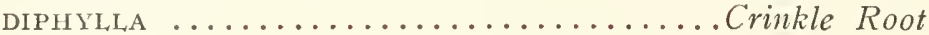

\section{DIANTHERA,}

Americana ............................. Willow

Favorite plant with cattle for food along our creeks, producing a large flow of milk. The flowers purplish and the separated cells give appearance of two anthers. Fertilized by butterflies and the so-called snake feeders.

\section{DICENTRA,}

CUCULLARIA ............... Dutchman's Breeches

Canadensis .............................. Correl

The firmly closed two spurred petals would seem to prevent intrusion of insects, but by means of gauze placed over flowers, no seeds are set, proving pollen from other flowers is necessary. The rounded spurs make the first named, as they resemble Dutchman's breeches.

DIOSCOREA,

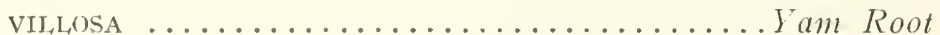

The rhizonnes are used in a medicinal way and the roots or "yams" as articles of food. A bad name, for the plant is never villous, and often nearly smooth.

DROSERA,

ROTUNDIFOLIA $\ldots \ldots \ldots \ldots \ldots \ldots \ldots \ldots \ldots \ldots$ Sundeí

DYSODIA,

CHRYSANTHEMOIDES ..................... Marigold 

DULCHIUM,

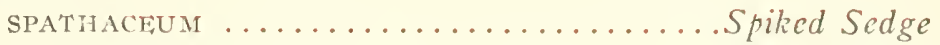

ECHINODORUS,

RADICANS .............................. Sack

ECHIUM,

VULGARE $\ldots \ldots \ldots \ldots \ldots \ldots$. . . . . . . . Ber's Bugloss

\section{ECHONOCYSTIS,}

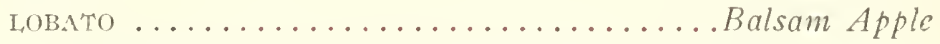

A beautiful rapid-growing climber with triple tendrils, and is cross fertilized largely by beetles. The name means hedgehog, in allusion to the armed fruit.

\section{ELEOCHARIS,}

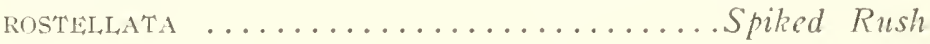

\section{ELODES,}

VIRGINICA $\ldots \ldots \ldots \ldots \ldots$................ Wort

\section{EPIPHEGUS,}

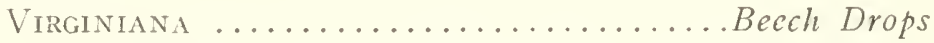

Saprophytic plants, upper open flowers are sterile, the lower ones which never expand, accomplish the continuance of their kind.

\section{EPIGOEA,}

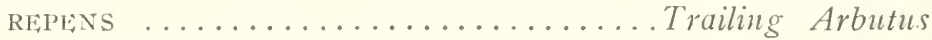

It is hard to realize the plant with its creeping habits is actually a shrub. They were the first flowers to greet our Pilgrim Fathers, and are pedcled every spring under the title of the Plymouth Mayflower. 


\section{EPILOBIUM,}

Augustitifolium....................... Herb

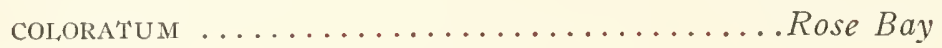

\section{EQUISETUM,}

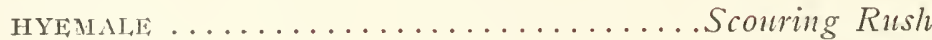

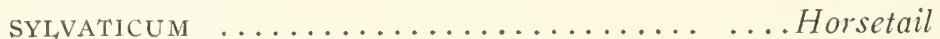

PRATENSE ...................................... Tail

\section{ERYTHRONIUM,}

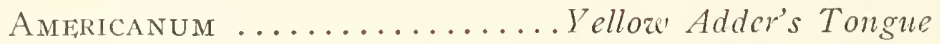
ALBIDUM ................White Adder's Tongue

These flowers are adapted to long tongued insects. The bumblebee Bumpus Pennsylvanicus and the butterfly Colias philodice are often seen entering the flower bell and issue besprinkled with pollen.

\section{ERIGERON,}

BELLIDIFOLlUM $\ldots \ldots \ldots \ldots$ Robin's Plantain

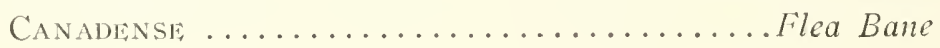

\section{ERECHTHITES,}

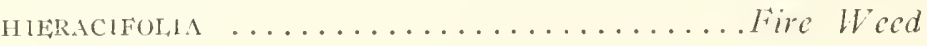

\section{EUPHORBIA,}

CORROLLATA ................. Flowering Spurge

HYPLRICIFOLIA ................Flowering Spurge

ESULA ....................... Flowering Spurge

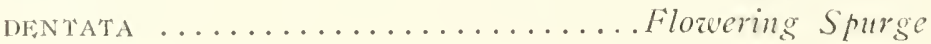

\section{EUONYMUS,}

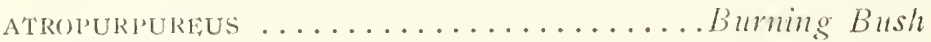

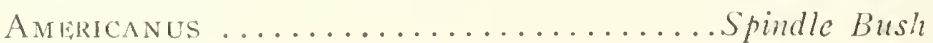




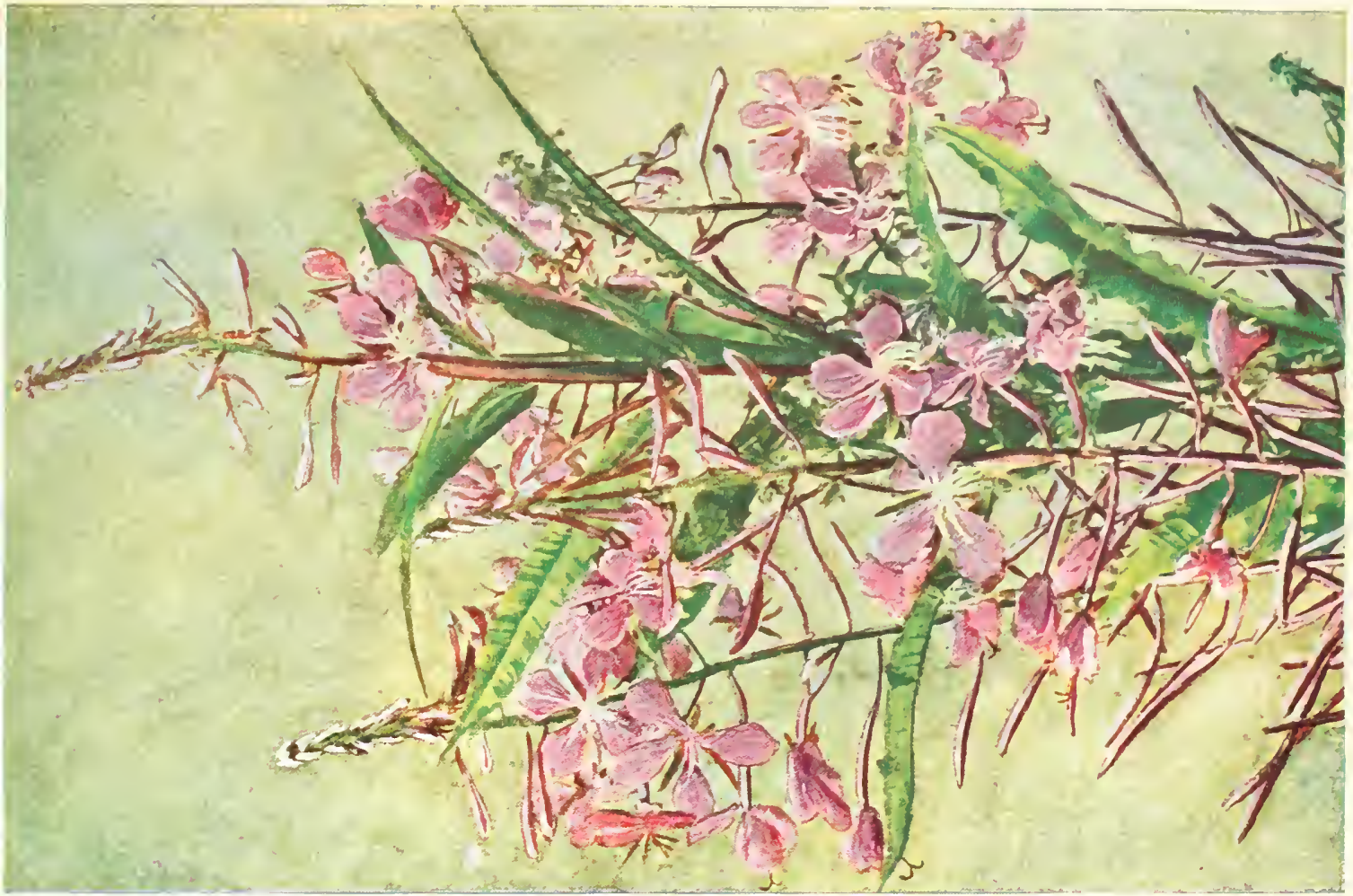

\&

$x=-12$

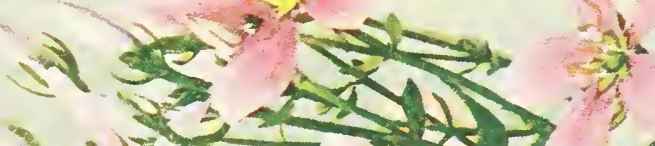

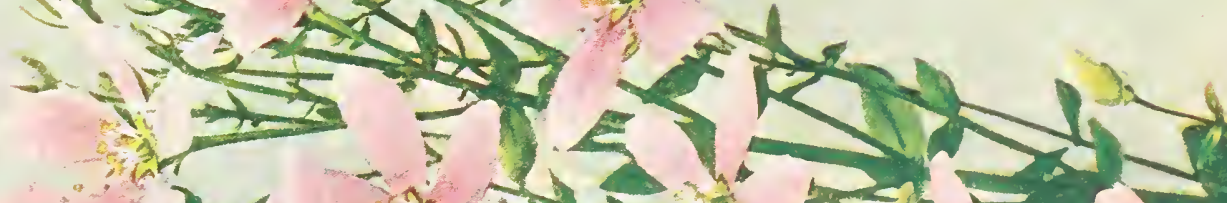

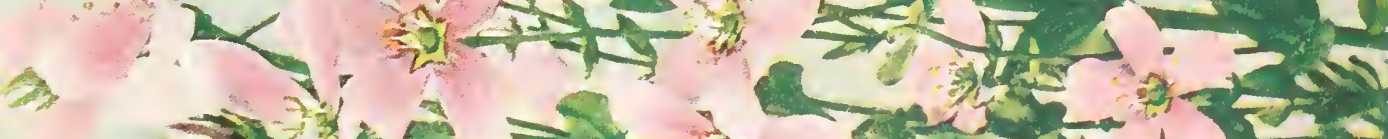

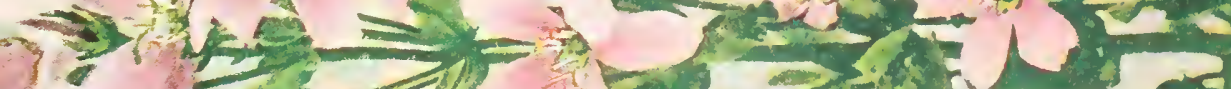

$-\infty$
-1

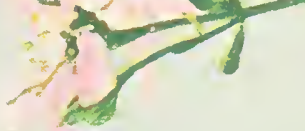




\section{EUPATORIUM,}

PURPUREM ....................Joe Pye Weed

AGERATOIDES ................ White Snake Root

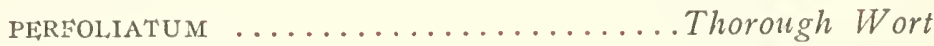

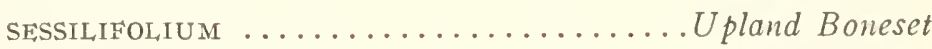

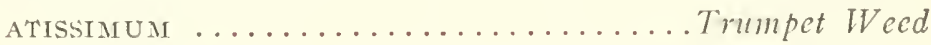

These heads of flowers show that in "union there is strength" by being composite, attractive to insects. The first-named to commemorate Dr. Joe Pye an Indian doctor who had great reputation in curing typhoid fever by its $11 \mathrm{se}$.

\section{FEDIA,}

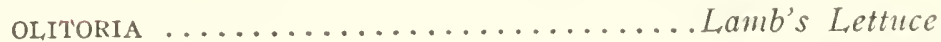

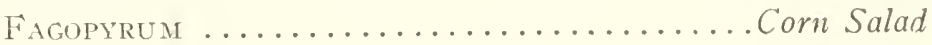

\section{FILAGO,}

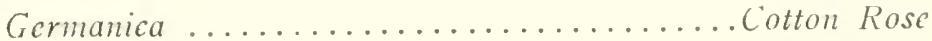

\section{FLOERKEA,}

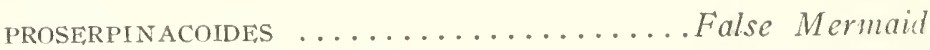

\section{FRAGARIA,}

ILLINOENSIS .....................eld Strawberry

VESCA $\ldots \ldots \ldots \ldots \ldots \ldots$ Cliff Strawberry

Six natnral species are recognized, all belonging to F-vesca. The Illinoensis is the sonrce of the famous Hovey's Seedling and later of the Wilson's Albany, whose production marked an epoch in strawberry culture. Some botanists condemn calling it a berry as the fruit or achaena are borne on its exterior. Iraak Walton, in his Angler, quotes Dr. Boteler as saying. "Doubtless. God could have marle a better berry, but, doubtless. God never dirl." 
FUMARIA,

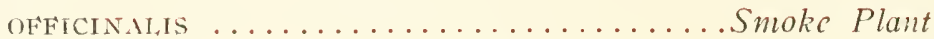

\section{GAULTH巨RIA,}

PROCUMBENS ................Wintergreen

MACULATUM ................Wintergreen

\section{GALIUM,}

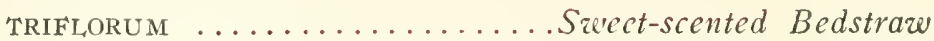

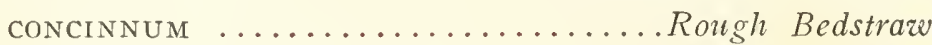

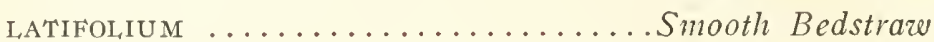

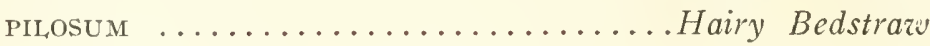

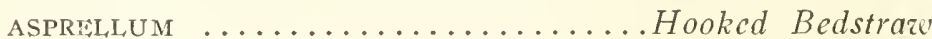

CIRCAEZANS .................Wild Liquorice

\section{GAURA,}

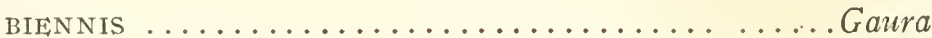

\section{GENISTA,}

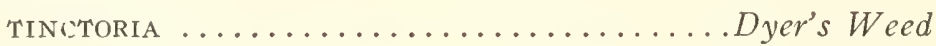

\section{GENTIANA,}

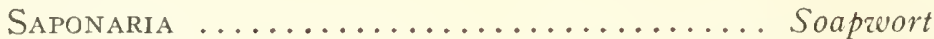

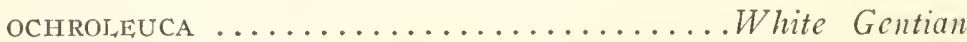

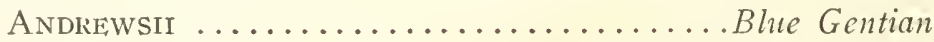

QUINQUEFLORA ...............Five-flozered Gentian

They bloom with the late frosts, when birds have flown. The closed flowers have been used to disprove cross fertilization by insects, but bees have been noted puncturing the petals of the tight closed bottle shaped corolla. The juices of the plant are very bitter and used as a substitute for quinine.

\section{GERARDIA,}

TENNIFOLIA .................... Purple Gerardia

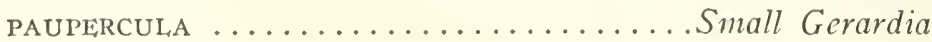




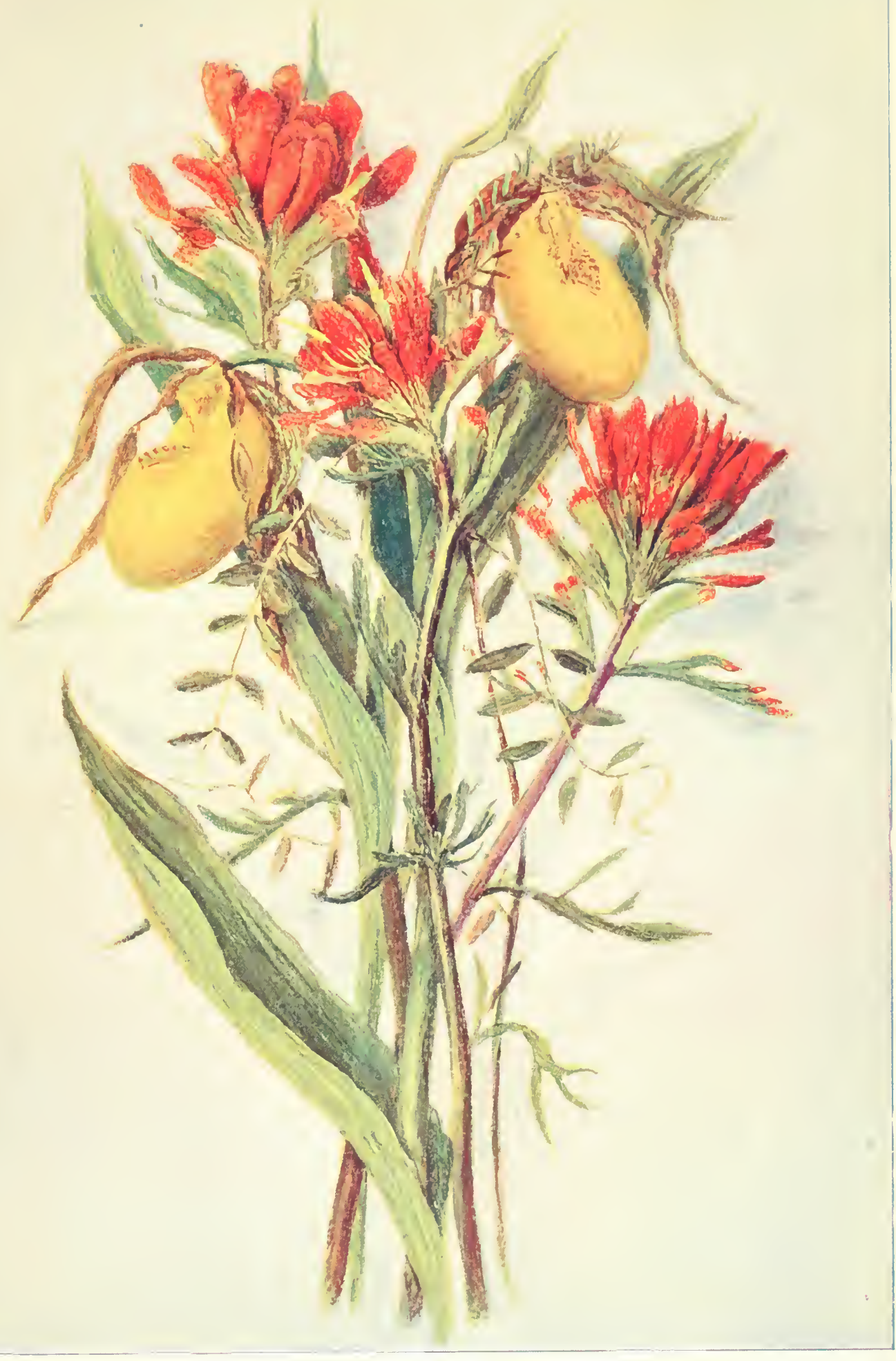


GEUM,

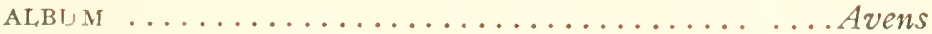

\section{GERANIUM,}

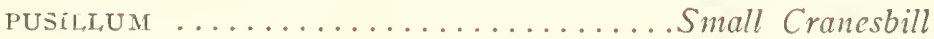

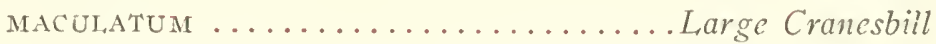

The long fruit bearing beak resembling the bill of cranes.

Sprungel, the German scholar, first noted the close relation as to form between flowers and insects. Others have noted the number of species of insects is related to the number of species of plants, each shaping those of the oiher.

\section{GILLEN:A,}

TRIFOLIATA ............................... Physic

GOODYERA-ORCHIS,

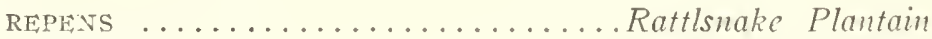

PUBESCENS ...............Rattlesnake Plantain

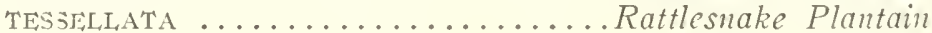

\section{GRATIOLA,}

VIRisiniANA $\ldots \ldots \ldots \ldots \ldots \ldots$ Hedge Hyssop

HAMAMELIS,

VIRGINICA ............................... Hazel

The polygannous showy flowers come out late in autumn, maturing the next summer its torpedo shaped seeds, which it expels with remarkable force to a distance of forty feet. It has lately been discovered that the pollen after germinating upon the stigma, with comparative rapidity until winter, when the upper part of the pistil dies and the pollen tube passes the winter in that part of the pistil which has a protective covering of hairs. In the spring the pollen tube resumes its growth and perfects fertilization of the plant. 
HABENARIA-ORCHIS,

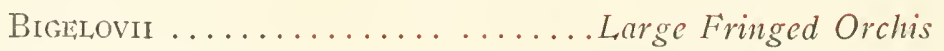

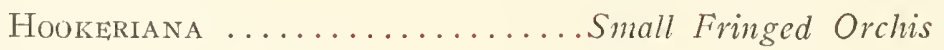
Ciliaris .................. Yellow Fringed Orchis Psycodes ................. Purple Fringed Orchis BLEPIIARIGLOTTIS .............White Fringed Orchis ORETCULATA ................. Spurred Fringed Orchis DILATATA .....................een Fringed Orchis

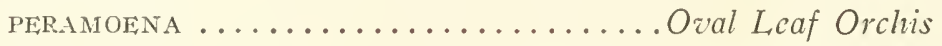
LACENA .................................. Orchis

The difference between these species is marked and distinct year after year. Variation is the universal rule in nature and this genus in all species shows that it exists everywhere. So there are no two faces exactly similar; so there are no two plants which do not vary to scme extent in structure : and today the naturalist wants to know the cause of the variations.

\section{HEPATICA,}

TRIDOLA ............................. Leaf

ACUTHIOBA ................................ Leaj

On sunny sicles of hills the leaves are tribola, or round lobed, and in shady nooks, leaves acute or pointed and sometimes five-lobed. The ancients believed nature indicated by shape to which her creations should be applied.

\section{HEUCHERA,}

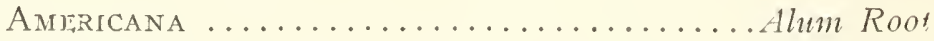

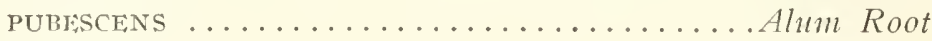

\section{HEDEOMA,}

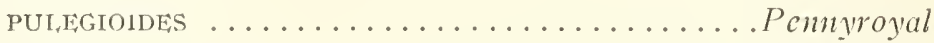
HISIIDA $\ldots \ldots \ldots \ldots \ldots \ldots \ldots \ldots \ldots$ Pennyroyal 


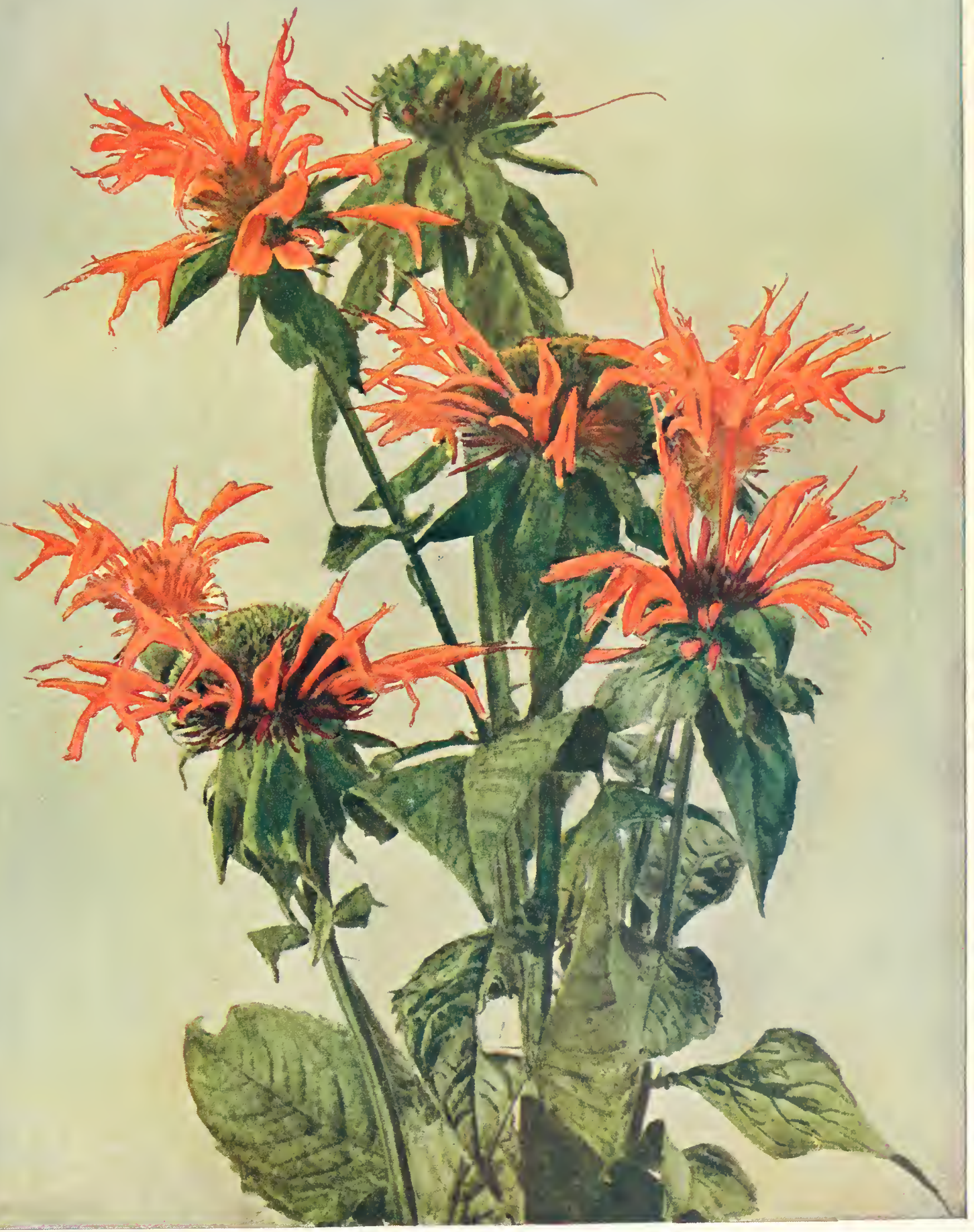

OSWEGO TEA OR BEE BALM. 

HELIANTHUS,

TUBERosus ........................... Artichoke

GIGANTEUS ..................... Sun-flowe?

HIRSUTAS .......................... Suntorver

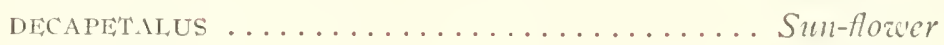

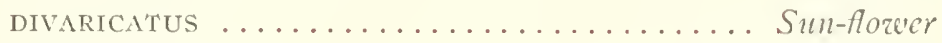

MiCROCEPHALUS ................... Sun-floter

The divaricatus is claimed to be original of the artichoke. The other species in mytlology sacred; as the flowers always face the sun. They are used in the temples as symbolizing constancy and service to the sun-god.

HIERACIUM,

VENOSUMI ...................Rattlesnake IVeed

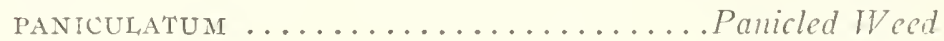

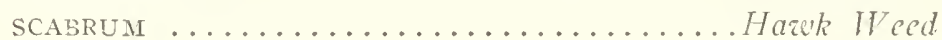

HOUSTONIA,

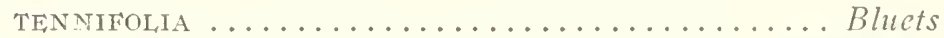

LONGIFOLIA .................... Innocence

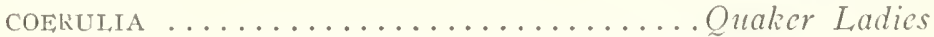

They are dimorphous with short pistils and and stamens. The tall secure pollen from tal and short from short pistil or stamened plants, thus preventing self-fertilization.

HYPOXIS,

ERECTA $\ldots \ldots \ldots \ldots \ldots \ldots \ldots$ Star Grass

HYDROPHYLLUM,

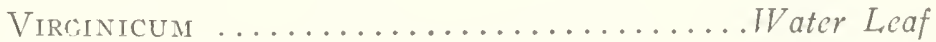

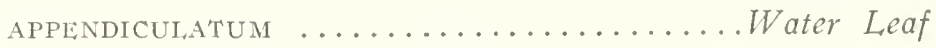

HYDRANGEA,

ARBORESCENS ...............Wild Hydrangea 
HYDROSOTYLE,

RANUNCULOIDES ............... Pennywort

HYPERICUM,

Corymbosum ......................... John's Wort

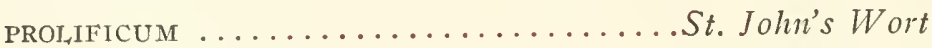

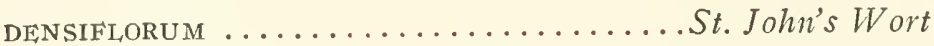

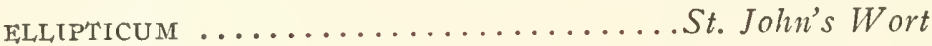

PERFORATUM ........................ John's Wort

ILEX,

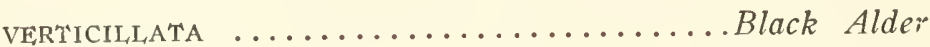

ILYSANTHES,

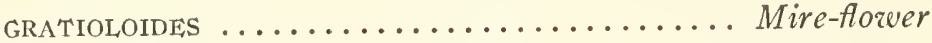

IMPATIENS,

FULVA .............................. Weed

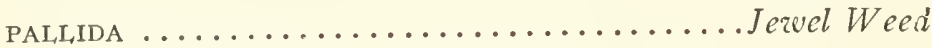

Cleistogamous flowers fertilized in the bud.

The seed pod bursting with violence, scatters

the seed without aid of elements or animals.

IODANTHUS,

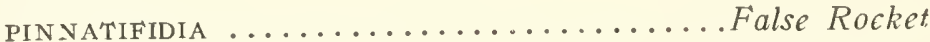

IRIS,

VERSICOLOR ......................... Fla Fla

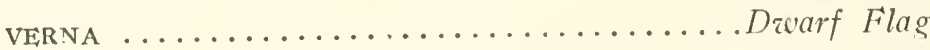

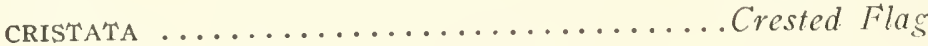

ISANTHUS,

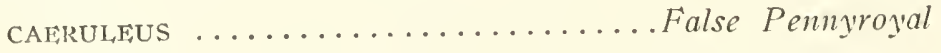

JEFFERSONIA,

DIPHYLLA $\ldots \ldots \ldots \ldots \ldots \ldots$ Twin-leuf 


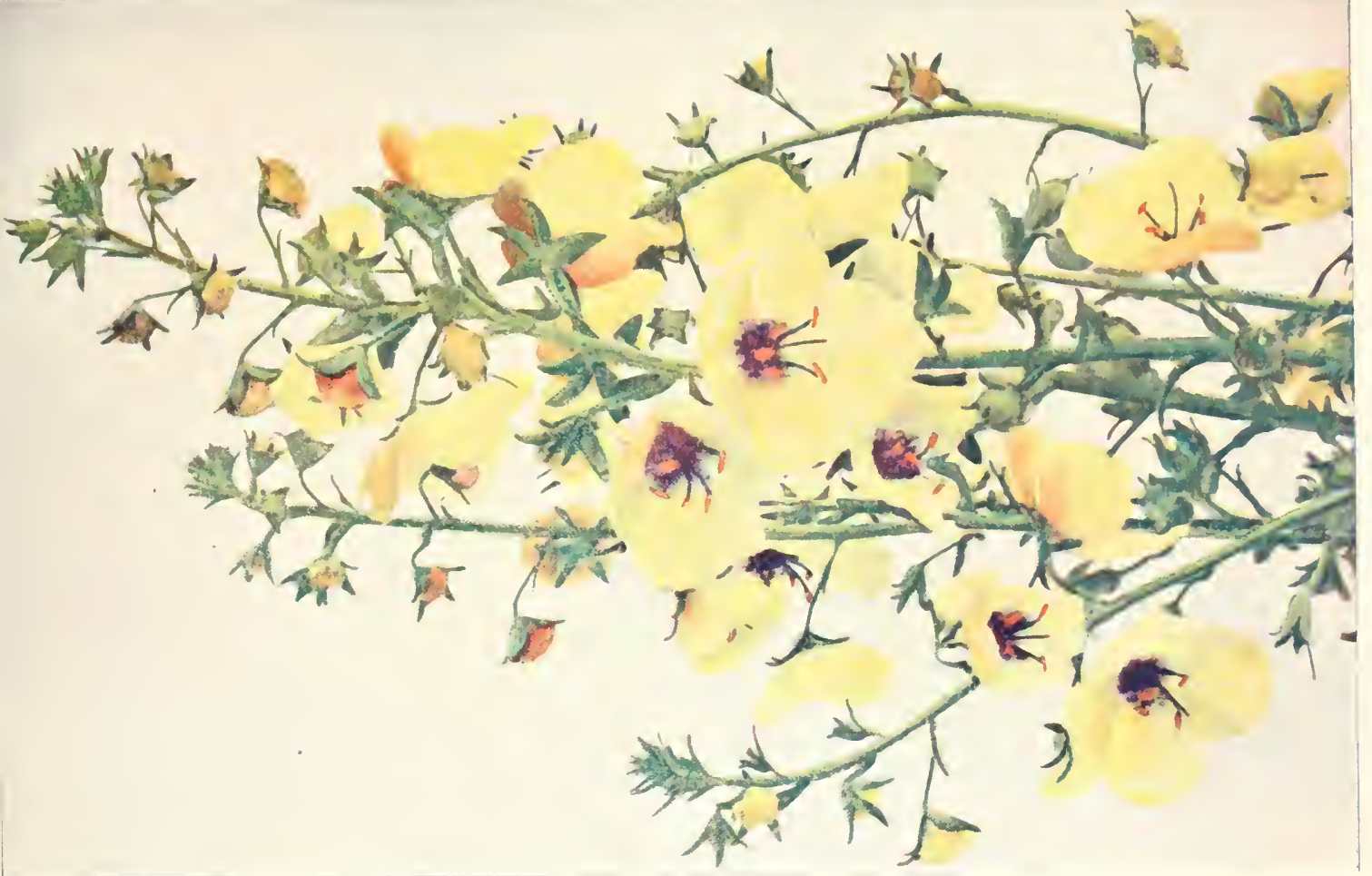

空

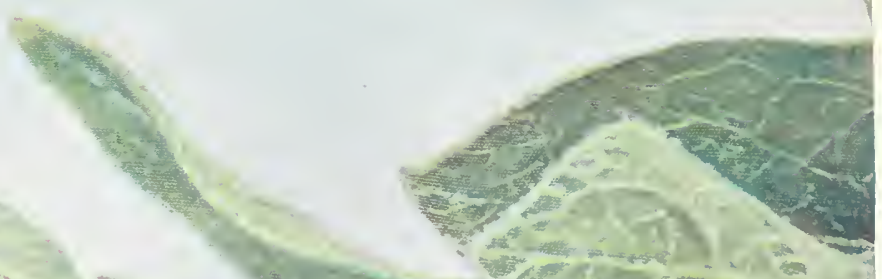

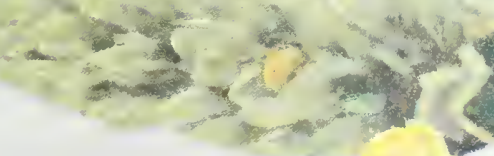
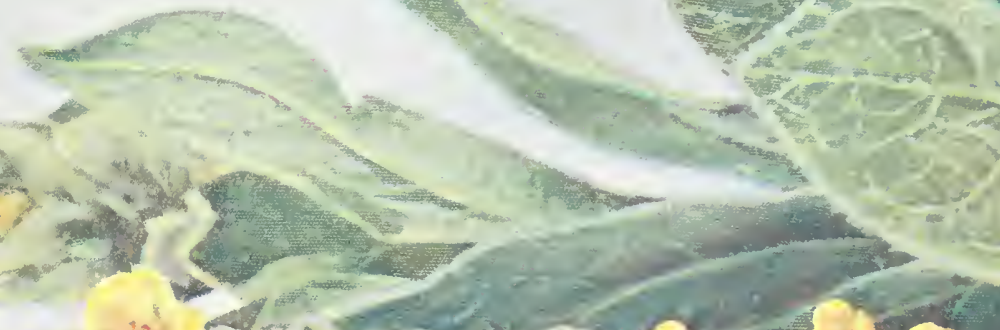

JUNCUS,

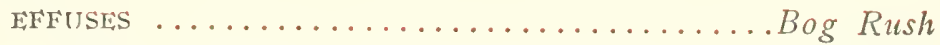

The soft pliant stems much sought after by basketry clubs, as they easily take up colors and work up beautifully into baskets.

KALMIA,

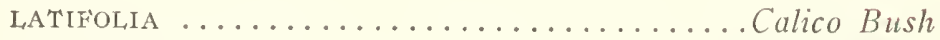

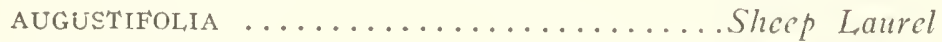

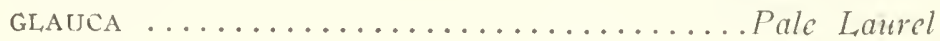

Through Apollo and the emperors, Tiberias and Augustus, the legends of laurel are dramatic. The use of same was forbidden to rofane services; even today many count it a good omen to decorate homes for Christmas. Farmers persist in exterminating laurel as poisonous to sheep. Others ruin many fine groves hunting for the knotty roots to make pipes and souveniers.

KRIGIA,

VIRGINICA $\ldots \ldots \ldots \ldots \ldots \ldots \ldots \ldots$ Dandelion

\section{LESPEDEZA,}

TINCHORIA $\ldots \ldots \ldots \ldots \ldots \ldots \ldots \ldots$ Bush Clover

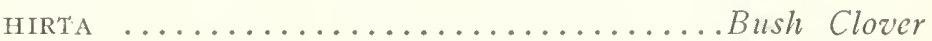

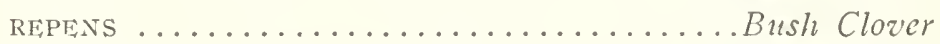

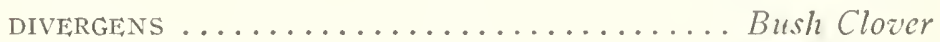

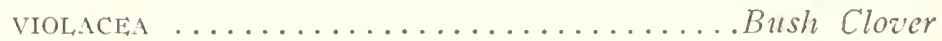

They bear two kinds of flowers, the showy ones with petals never fruit, the others without petals extremely fertile. Butterflies and bees are constant visitors. The plant named for a Spanish governor of Florida.

\section{LEPIDIUM,}

INTIRMEDIUM

Pepperwort 
LEDUM,

LATIFOLIUM ................................ Tea

LINUM,

usi'AATISSIMUM $\ldots \ldots \ldots \ldots \ldots \ldots \ldots$ Flax

LIPARIS-ORCHIS,

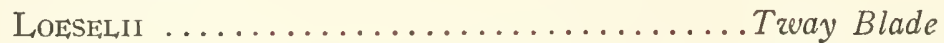

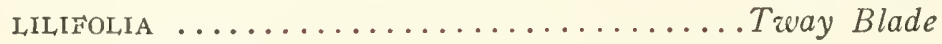

A pretty little orchid, the racemes with purplish llowers, and fat or shining leaves. To have success in germinating the seeds they must be sown in fungus-infected soil.

\section{LIATRIS,}

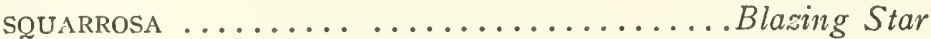

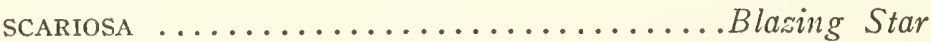

Showy spikes of purplish flowers, often three feet in length. Grows in great masses near Morado park, with polygala, golden rod and lobelia. Flowers are visited by the honey bee and orange banded hornets.

\section{LILLIUM,}

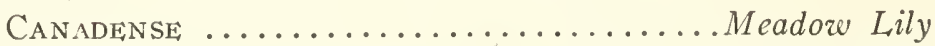

SUPERBUM ............................. Lily

'The pollen is largely distributed by the humming birds; the smallest, most exquisite and unabashed tropical jewel, that assists in fertilizing all our tubular flowers. The bird's tongue is perforated, forming cylindrical tubes, capturing insects in flowers, as well as nectar. They cover their nests with lichens and line them with down of cat tails and ferns. In extracting nectar from flowers, they poise on wing, and the only bird that flies backward out of flower tubes.

LINARIA,

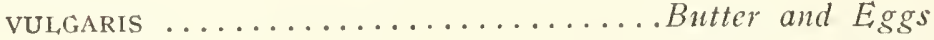

CANADENSIS ...................... anter Eggs 


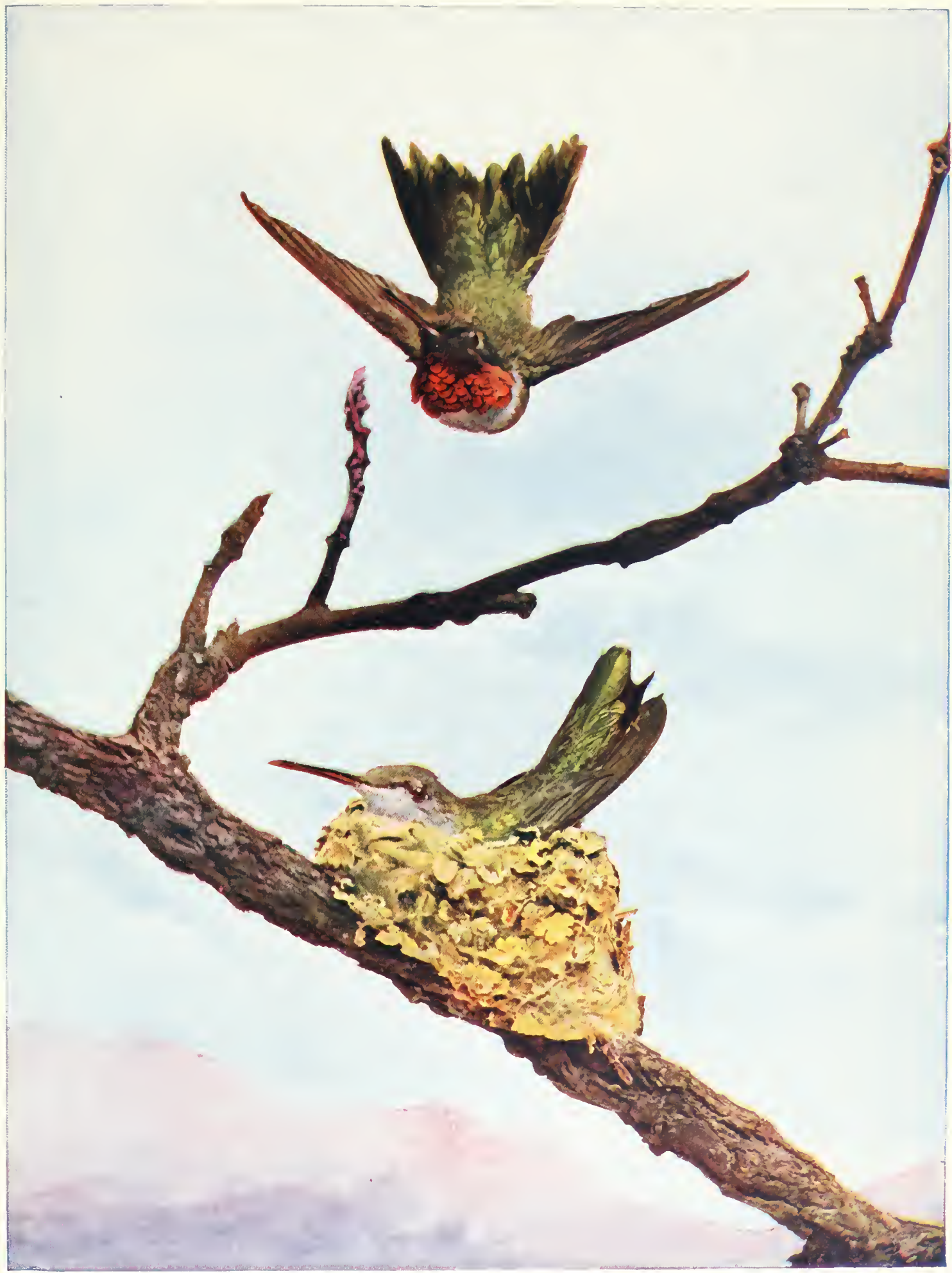





\section{LIPPIA,}

LANCEOLATA .................... Fruit

\section{LONICERA,}

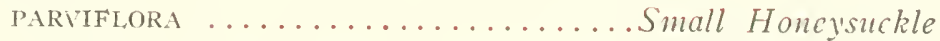
CILIATA ....................Fly Honcysuckle

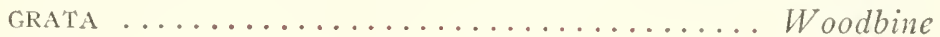

\section{LOBELIA,}

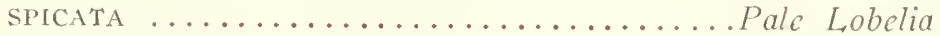

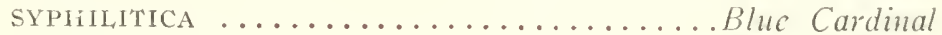

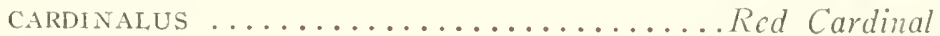

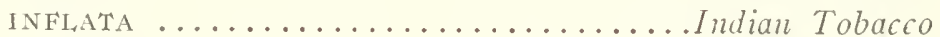

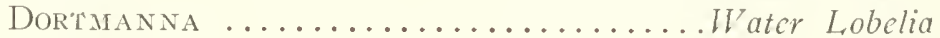

\section{LUDWIGIA,}

ALTFRNIFOLIA .............................. Sed-bo.t

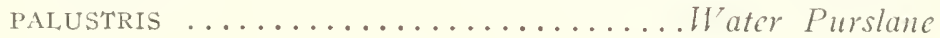

\section{LYCHNIS,}

VESPERTINA ................Evening Cocklc

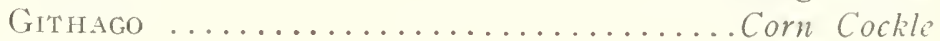

\section{LYCOPUS,}

Virrinicus ..................... Bugle Weed EUROPAEUS ................Water Horchound

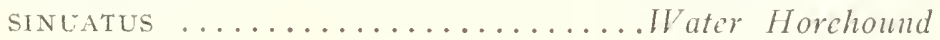

\section{LYSIMACHIA,}

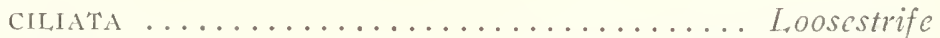
THVRSIFLORA ................ Tufted Loosestrife

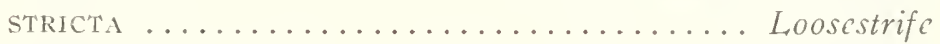

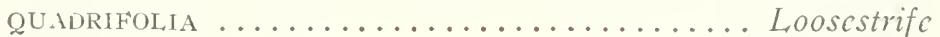

NUMiLULARIA ................... Moneywort

The last is a pretty trailing vine growing in the river channel beds among the gravel and stones. The golden yellow flowers attracts many insects. 


\section{LYCOPODIUM,}

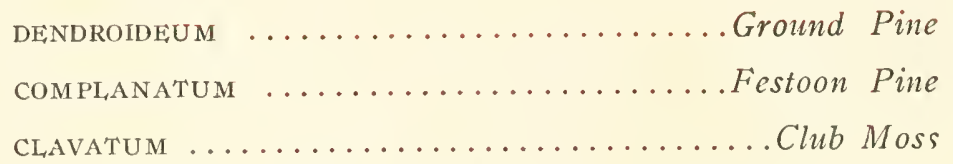

Variation in these plants seem to be more than evolution, being guided by some intelligent power having definite and ordered results. They were not left to chance, and always an end in view, with regular methods adapted to that end. The subtile spores discharge copious sulphur-colored inflammable powder.

\section{LYGODIUM,}

PAL,MATUM .Climbing Fiern

Rootstalks with climbing fronds. From each mid-vein veinlets arise obliquely curving outward to edge of lobes. Connecticut passed a blue law in 1869 with a penalty of one hundred dollars for gathering this fern. This is the only state law, where a wild plant has received special protection on account of its beauty.

\section{MAIANTHEMUM,}

BIFOLIA .................... Two-Leaved Seal

MARUTA,

Cotula $\ldots \ldots \ldots \ldots \ldots \ldots \ldots \ldots \ldots$. W Weed

MALVA,

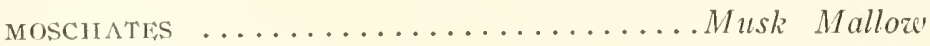

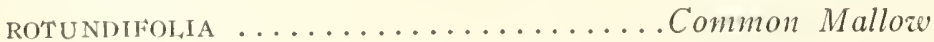




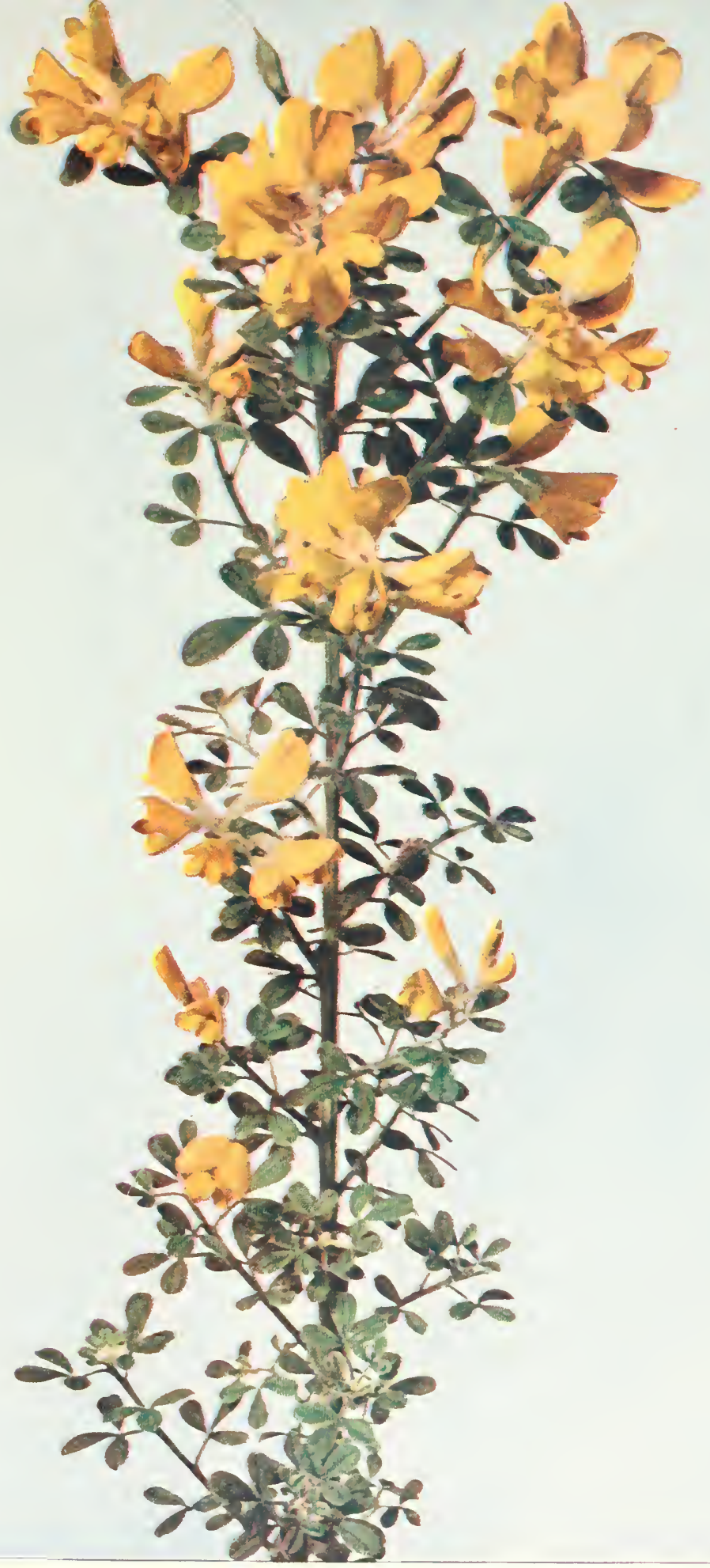



MELITOTUS,

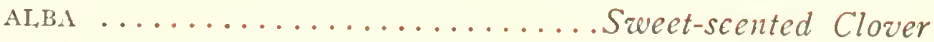

MEDICAGO,

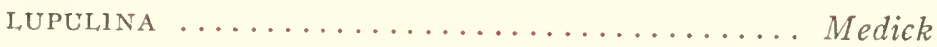

MEDEOLA,

Viriniana ........................ Cumber Root

Named for the sorceress, Medea, from the imaginary notion that it possesses great medicinal virtues. Always found growing with Orchids.

MENTHA,

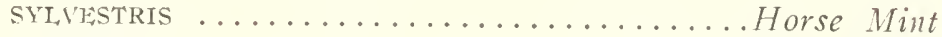

PIPERITA ......................... Mer Mint

AQUATICA ........................... Wint

VIRIDIS ................................ Mint

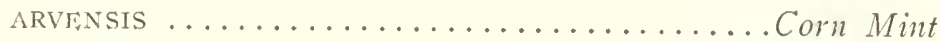

MERTENSIA,

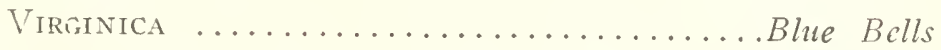

MELANTHIUM,

Vircinicuai ............................ Flower

MICHELLA,

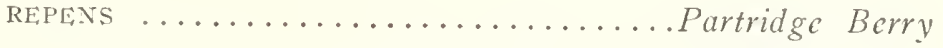

The white fragrant flowers are rarely ciimorphous or completely confluent in one. Cross fertilized mainly by small butterflies and bees. The scarlet berries are edible remaining through winter. This evergreen plant is common in America, Mexico, Asia and Japan. Supposed to have had common origin, being separated by descent of glacial periods. 
MITELLA,

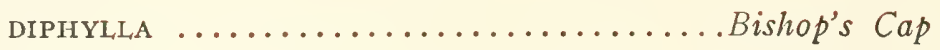

MIMULUS,

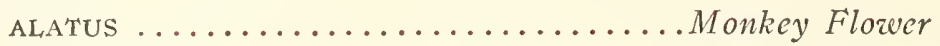

RINGENS ................................. Flower

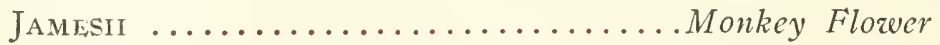

MOLLUGO,

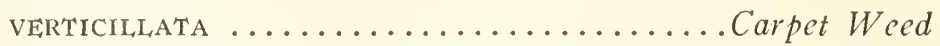

MONARDA,

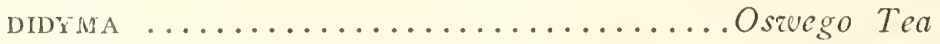

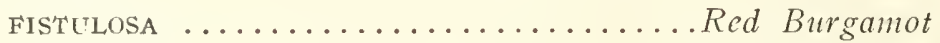

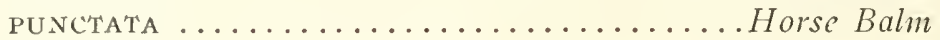

MOSSES,

TUNGERMANIA

HYPNUM-ADUSTUM

DESMATODON-AVENACENS

BARTRANIA-PONISFOMIES

Cylindesthesium-SEDUCTRIA

POLYTRICHIUM-FORMOSUM

HyPNUM-TAMARISSIMUM

MERCHANTIA-POLYMORPHIA

DEERHORN-MUSHROON.

Mosses are interesting on account of the important part they play in the economy of nature. The mossy coverings of the forest collect the rainfall like a sponge, holding back excessive torrents; while the bog moss forms peat and other mosses grow on rocks producing by decay a thin layer of humus in which the seeds of higher plants take root. They Jave capacity to endure droughts and of suspending their growth in dry and resuming it again in moist weather. Among plants none of a higher order are closely allied and the chasm which divides mosses from all other jlants, is the widest in the whole vegetable kingdom. 


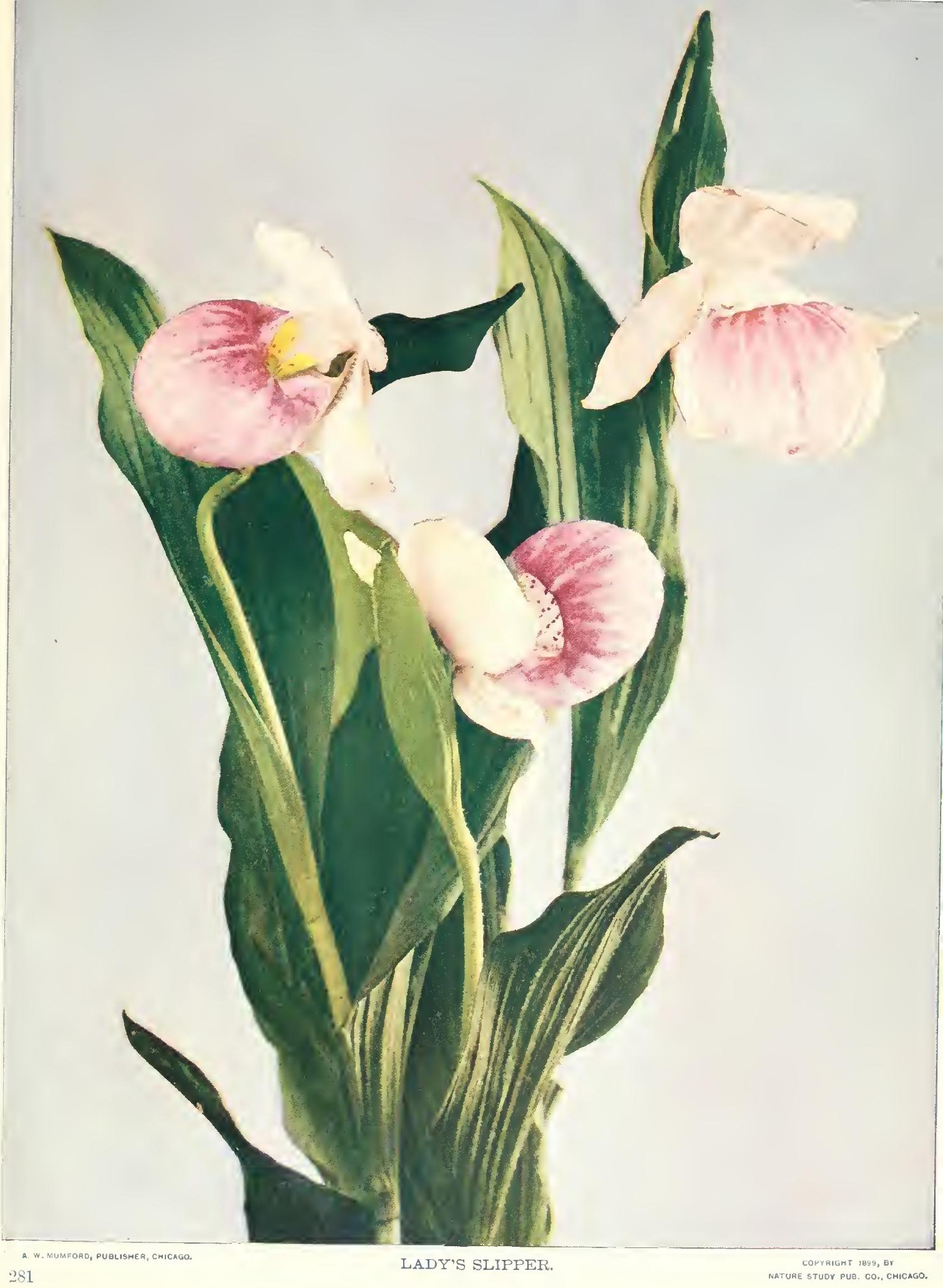



MONOTROPA,

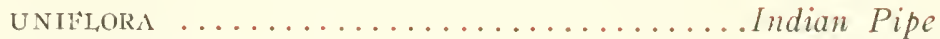

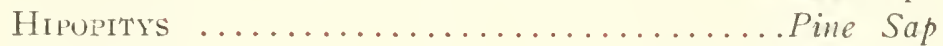

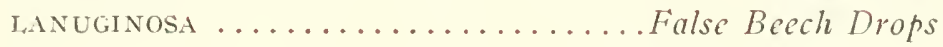

MYOSOTIS,

PALUSTRIS .................... Forget-me-not

LAX $\ldots \ldots \ldots \ldots \ldots \ldots \ldots \ldots$ Forget-me-not

VERNA $\ldots \ldots \ldots \ldots \ldots \ldots \ldots \ldots$ Forget-me-not

MYRIOPHYLLUM,

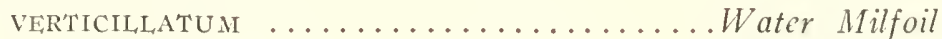

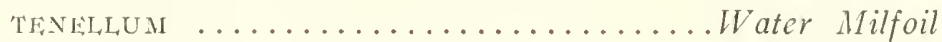

NAPAEA,

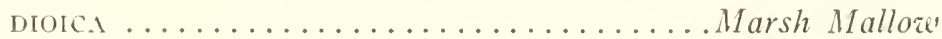

NARDOSMIA,

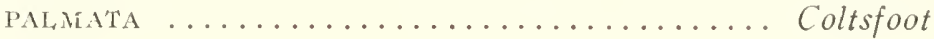

NABULUS,

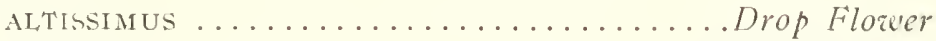

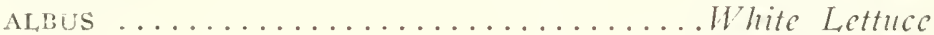

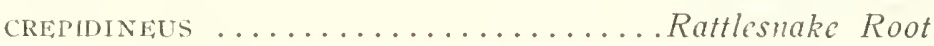

NEPETA,

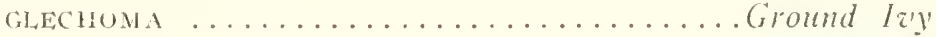

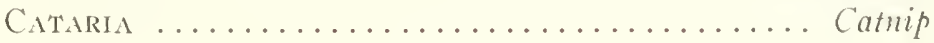

NICOTIANA,

RUsticA ......................Wild Tobacco

Named for John Nicot, who introduced the tubacco into Europe. The species number about fifty, all of American origin. Common in old fields: a relic of cultivation by the Indians. i he family dependent upon insects for cross fertilization. 
NUPHAR,

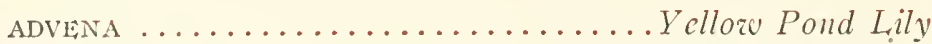

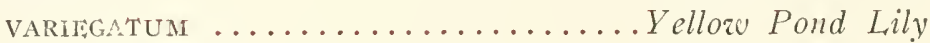

Pumilum ............................. Pond Lily

Flowers produced ail summer and from their olor called "brandy bottles." Many use the ruots as food, as also its farinaceous seeds. The sepals graduate into petals and the rows of petals into stamens. Reproduction is accomplished by the seeds, buds, bulblets, bulbs, tubers, cuttings, scions, and from leaves. Thus God's boundless resources of skill can accomplish either one purpose in a thousand different ways, or a thousand different purposes by one radical form and that form a leaf.

\section{OENOTHERA,}

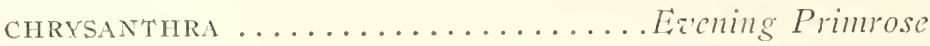

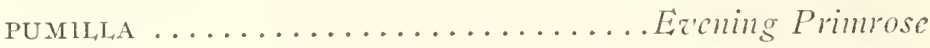

BIENNIS ..................Evening Primrose

GRANLIFLORA ................ Eiching Primrose

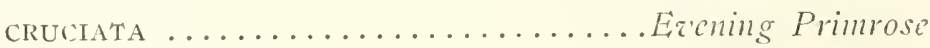

Plant varies greatly. Of nocturnal habits, the flowers opening near sunset and enit a fragrance to catch the large night moths. The roots are caten to provoke a relish for wine.

ONOCLEA,

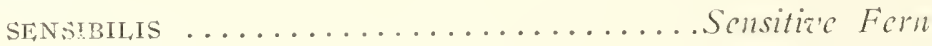

\section{ORCHIS,}

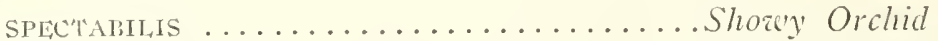

The flower is completely turned around and the

lip instead of being superior is anterior. The number of species is over five thousand, exceeding that of any other order. Twenty-eight hiave been found in beaver county. 


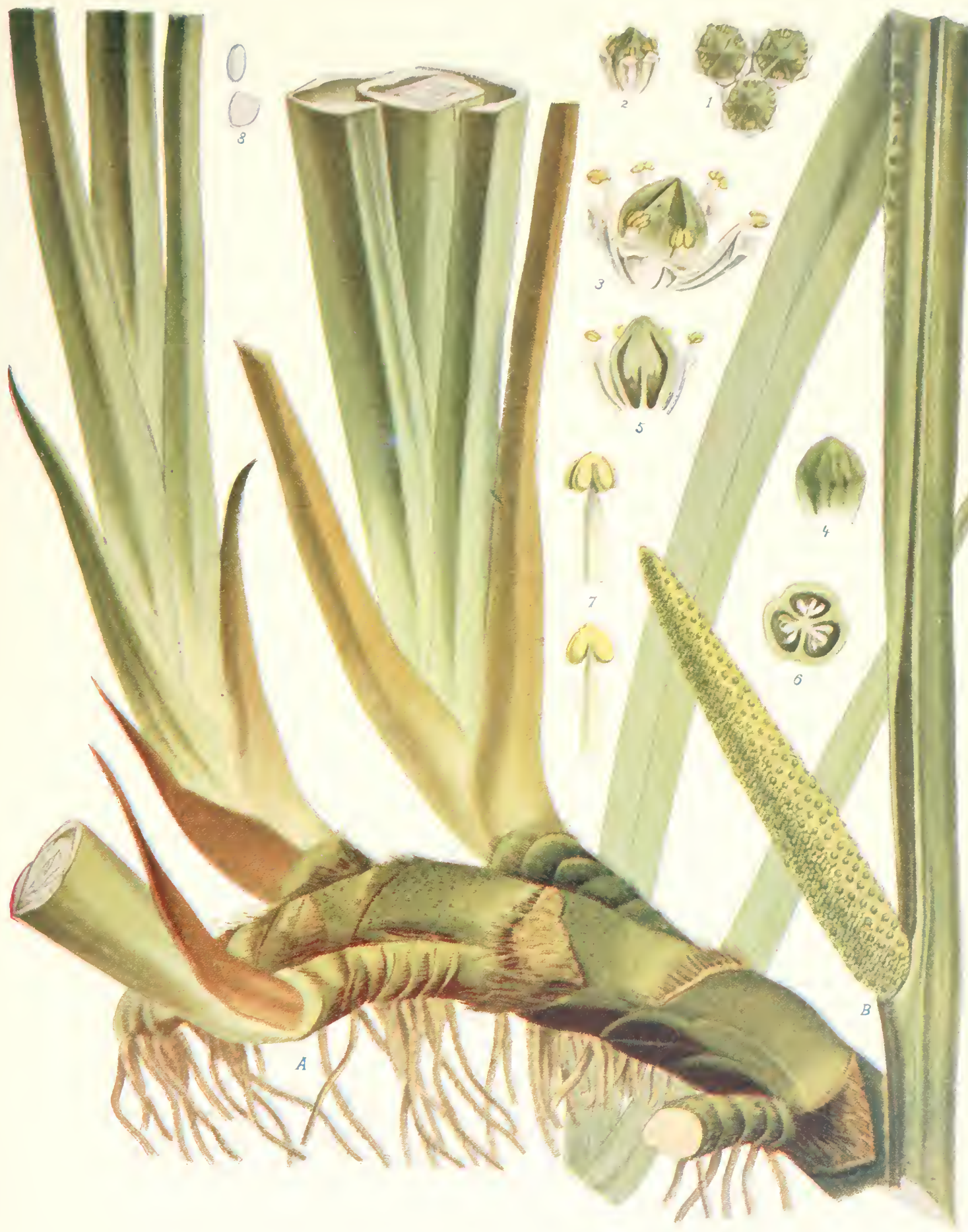



OSMORRHIZA,

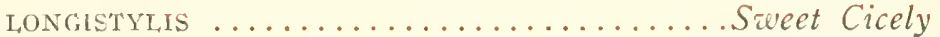

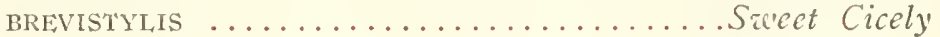

OSMUNDA,

REG ILIS .................................... Fern

CINNAMOMEA ................................... Fiern

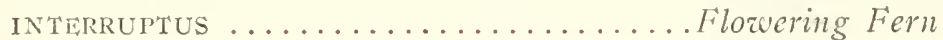

Named for St. Osmund, who came over from

Normandy in 1066 with William the Conqueror and who was made chancellor and reformed the liturgy. The rcot stalk continues many years, forming crowns of fronds or hummocks of imbricated stalk bases and interlacing roots. The base of the stalks are winged inw rapping the less developed like the scales of an onion. In Pine swamp the fronds grow six fret above the hummocks, curving outward and form such stately beatuty that they are deserving of name royal ferns. All the genera have the stalks winged and woolly, nor is there any absence of auricles or rounded lobes to distinguish the American from the European.

OXALIS,

VIOLACEA ............................ Sorrel

STR:CTA ......................Wood Sorrel

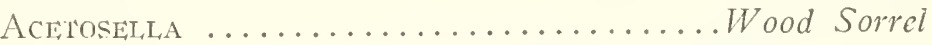

These plants bear small cleistogamous flowers underground that are self fertilized. They vield the salt of lemons due to oxalic acid. The triple leaves are reputed to have been used by Saint Patrick as a symbol of the Trinity.

OXYRIA,

DIGYNA $\ldots \ldots \ldots \ldots \ldots \ldots \ldots$ Montain Sorrel 
PAPAVER,

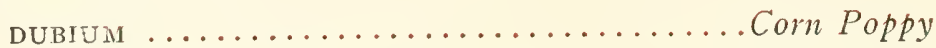

SOMnIFERUM $\ldots \ldots \ldots \ldots \ldots \ldots \ldots$ Corn Poppy

\section{PARONYCHIA,}

Dichотома ................Whitlow Wort

Canadensis $\ldots \ldots \ldots \ldots \ldots \ldots \ldots \ldots$ Betony

\section{PENTHORUM,}

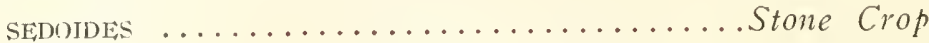

\section{PEDICULARIS,}

Canadensis ................................ Betony

The spikes bear the slender corolla as the head of a walrus and even with the miniature projections in initation of his tusks. The pollen is protected from rain, under the hooded upper lip. Bees are common visitors.

\section{PENSTEMON, ........}

PUBCSCENS .............................. Tongue

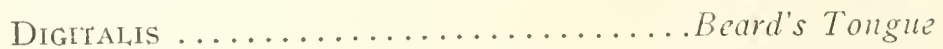

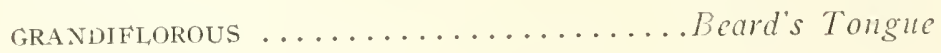

PHYTOLACCA,

DECANDRA .................... Poke Berry

\section{PHORADENDRON,}

FLAVESCENS ........................ Mistletoc

Of seventy-six species only this one found growing in our county. The plant much branched with scaly leaves, and having small spikes of yellow flowers: followed by white berries with vicous pulp, that are eaten by birds, thus scattering the seeds. The mistletoe is parasitic. most comnon on the shad or Juneberry tree. 

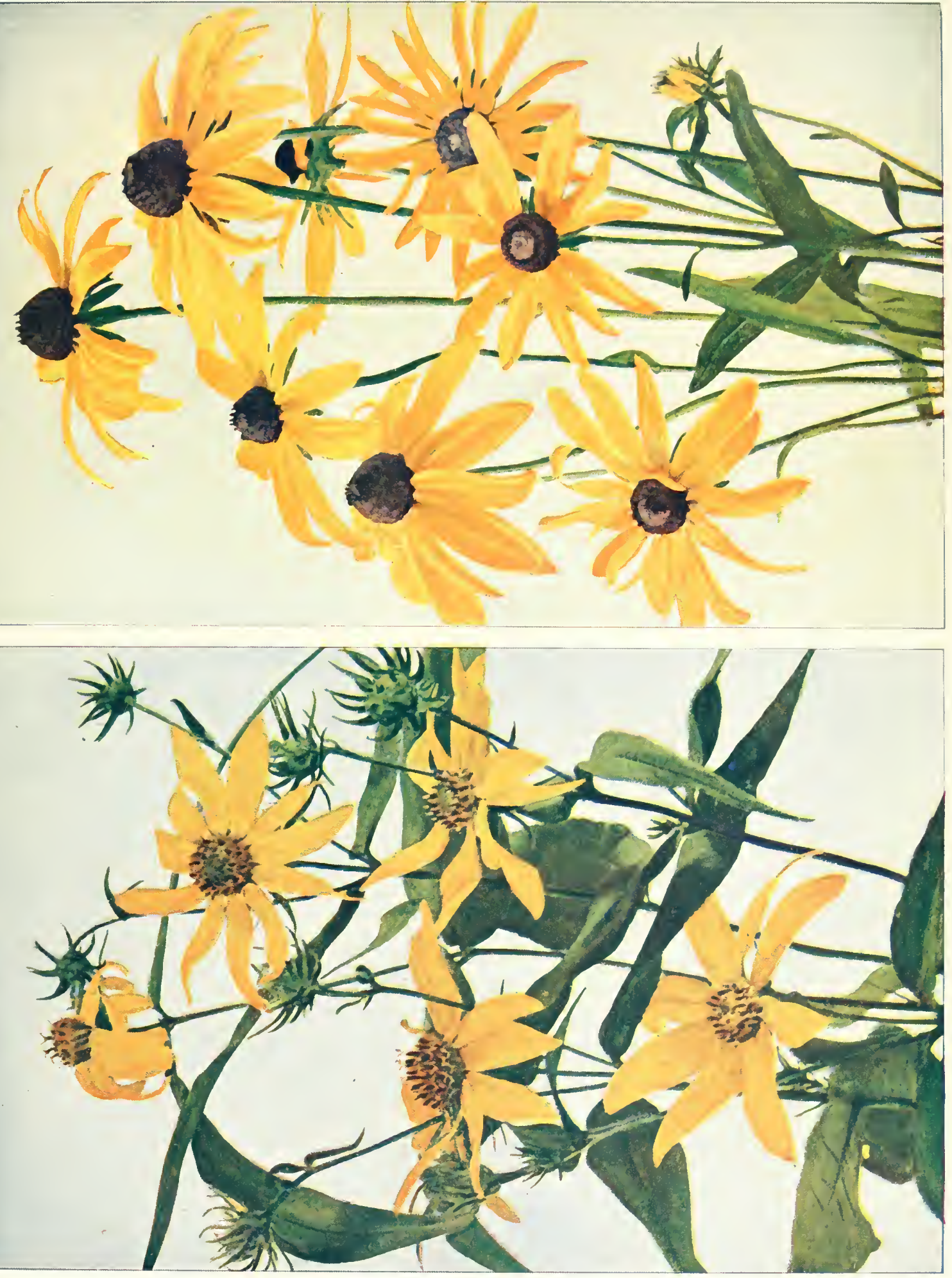

PHYRMA,

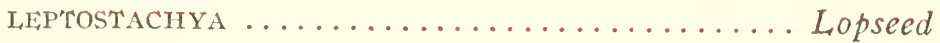
PHYSOSTEGIA,

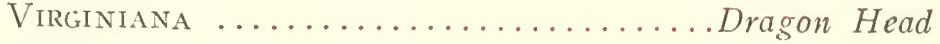
PHELIPOEA,

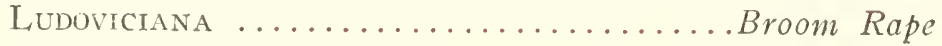
PHEGOPTERIS,

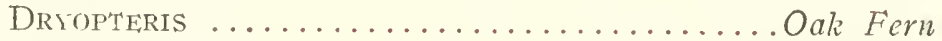

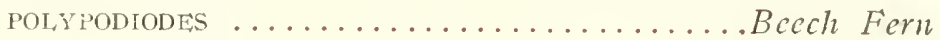

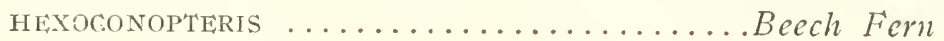
PHYSALIS,

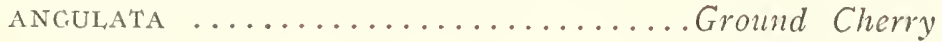
$\operatorname{viscos} \Lambda \ldots \ldots \ldots \ldots \ldots \ldots \ldots$ Ground Cherry Pennsyluanica .......................... Cherry

PHLOX,

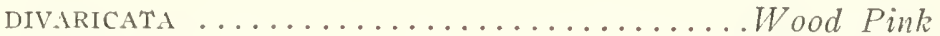
IYCHNIDIA $\ldots \ldots \ldots \ldots \ldots \ldots$. Swamp Phlo.r

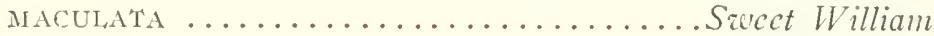

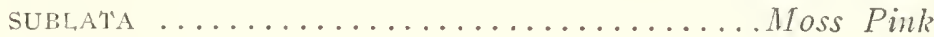
POLYGONUM,

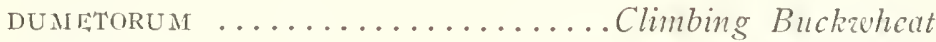
ORIENTALE ............................ Freather

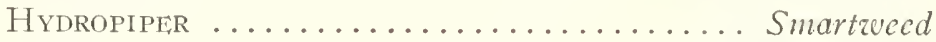

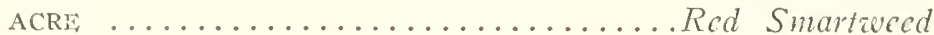
ARTICULATA $\ldots \ldots \ldots \ldots \ldots \ldots \ldots$ Jointwed

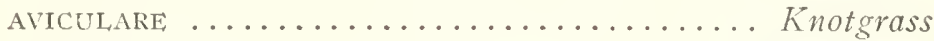

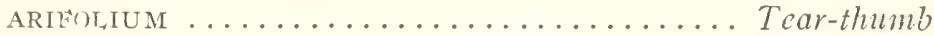

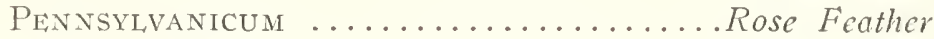

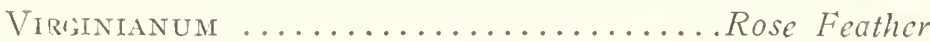
POLYPODIUM,

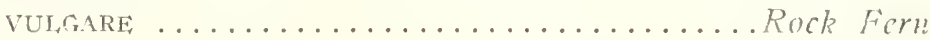


POLYGONATUM,

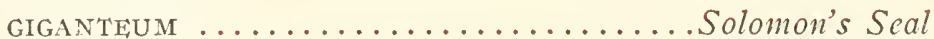

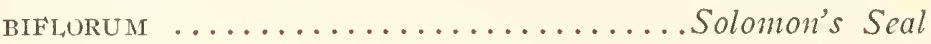

POLYGALA,

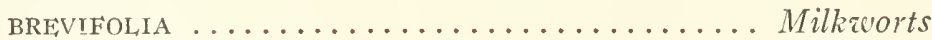

SANGUINEA $\ldots \ldots \ldots \ldots \ldots \ldots \ldots$ Milkworts

POLEMONIUM,

REPTANS ............................ Valcrian

PONTEDERIA,

CORD $\Lambda \mathrm{T} \Lambda \ldots \ldots \ldots \ldots \ldots \ldots$ Pickerel Weed

PODOPHYLLUM,

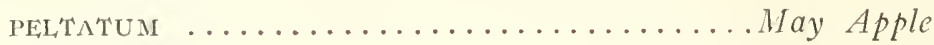

POTOMOGETON,

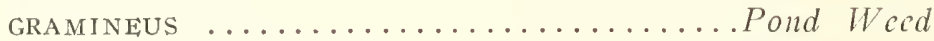

Those who desire to make further discoveries can with a microscope take up the Algae, a large group of cosmopolitan plants. In the order of Diatoms, many are found attached to these pond weeds. They vary greatly, showing plant forms that are very beautiful. There are many genera, and millions of species, srowing and moving everywhere, but how, is one of nature's secrets.

POTENTILLA,

Canadensis ....................... Fingers

PSORALEA,

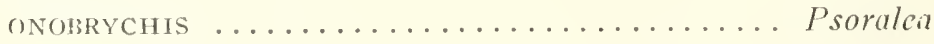

PTEROSPORA,

AndromedeA ............................ Drops 


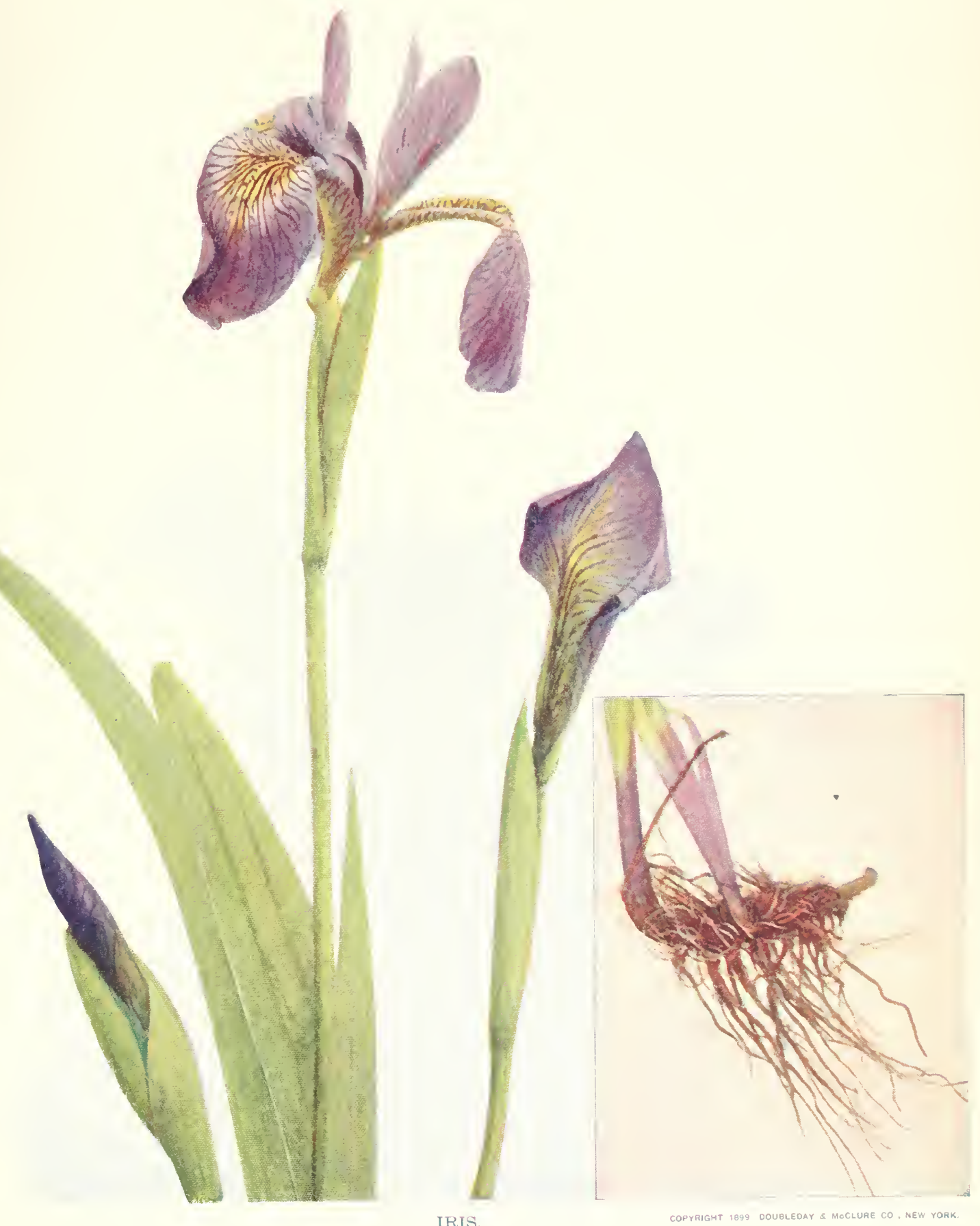


PTERIS,

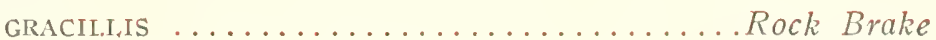

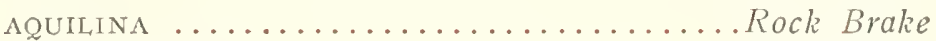

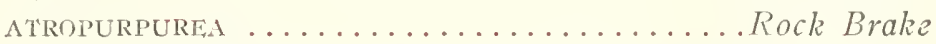

The genus Pteris consists of about one hundred species, widely distributed in America, Mexico and Europe. The transverse section of stems shows fibroid bundles of tissue; likened in appearance to "U. S." or the heraldic "displayed eagle" and in Europe it is also said they show "King Charles in the oak."

PYROLA,

ROTUNDIFOLIA ................False Wintergrecn

ELLIPTICA $\ldots \ldots \ldots \ldots \ldots \ldots$ Shin Leaf

PYCUAN'THEMUM,

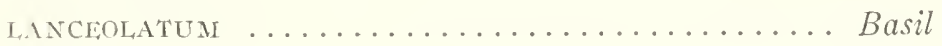

QUAMOCLIT,

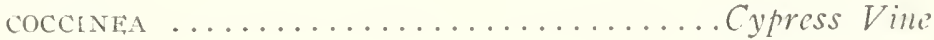

\section{RANUNCULUS,}

MURiCATUS ...........................

MULTIFIDUS $\ldots \ldots \ldots \ldots \ldots \ldots \ldots \ldots$ Buttercup

FASCICULARIS ...........................

BULBOSUS ...........................

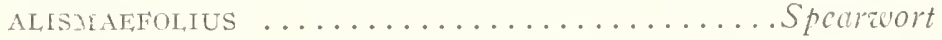

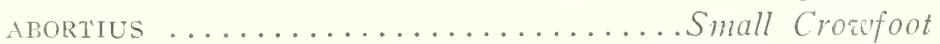

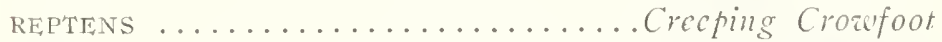

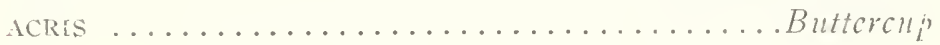

RHUS,

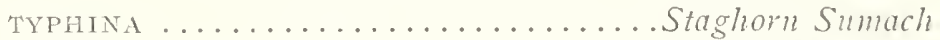

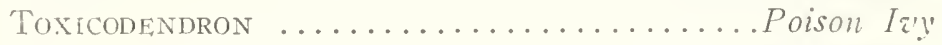

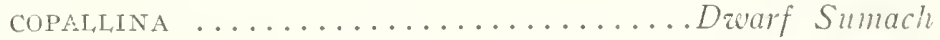

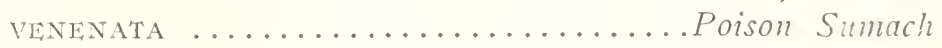

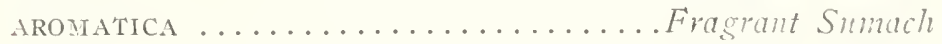




\section{RHODODENDRON,}

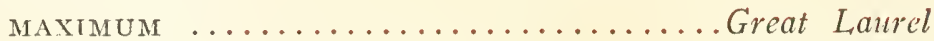

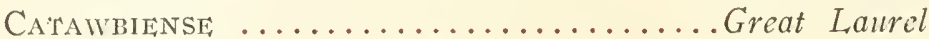

Both species are abundant on hills back from Monaca. They produce their new growth below the beautiful flowers, forming a terminal inflorescence destitute of leaves and developed from a large scaly bud. The cultivated species are R-Catawbiense hybridized with the tender exotic R-aboreum. The flower stems are hairy and sticky, keeping off insects not wanted, while the flowers are fertilized by many kinds of bees and night moths. They give us a broad hint to adopt them as our National Flower.

\section{RIBUS,}

FLORIDUM ............................. Currant

CYNOSBATI $\ldots \ldots \ldots \ldots \ldots \ldots \ldots$ Gooseberry

ROSA,

BLANDA $\ldots \ldots \ldots \ldots \ldots$ E. . . . . . Rorly Rose

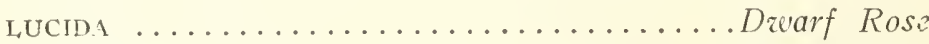

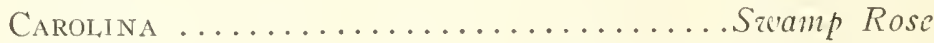

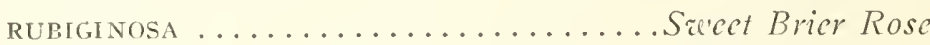

MICRANTHA ........................ Srect Brier Rose

\section{RUDEECKIA,}

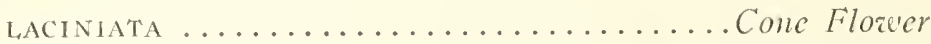

TRIBUt $\ldots \ldots \ldots \ldots \ldots \ldots \ldots$. . . . . Fllower

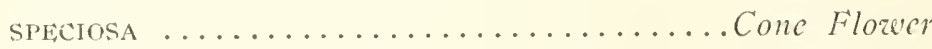

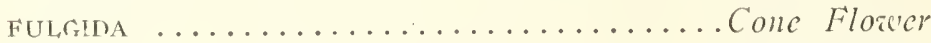

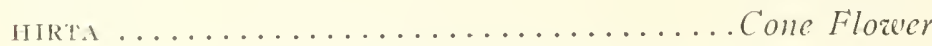

The last named species now common of recent introduction, with clover seed from the west. The small bee Halictus, bumble bees and larger butterflies are constant visitors. 



\section{RUBUS,}

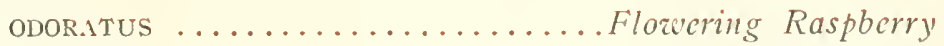

viltosus $\ldots \ldots \ldots \ldots \ldots \ldots \ldots$ Blackberry

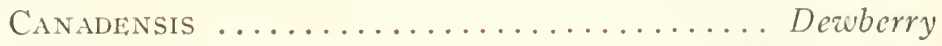

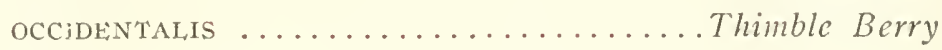

SARRACENIA,

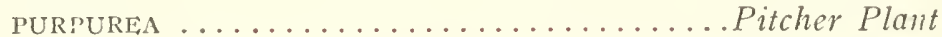

An interesting but almost extinct plant found stowing in the peat bogs of Pine swamp above New Gallilee. The curious inflated leaves are always partly filled with water and many lrowned insects, that not only contributed to the fertilizing but now to the sustenance. This species have leaf glands secreting a digestive fluid which aids in assimilating the insects. Now known that the pitcher leaves are kept filled through the roots.

\section{SAPONNARIA,}

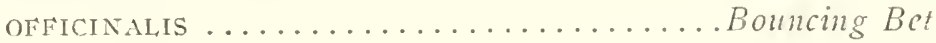

\section{SAGGITTARIA,}

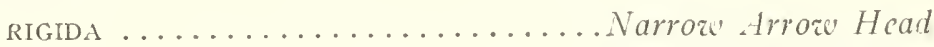

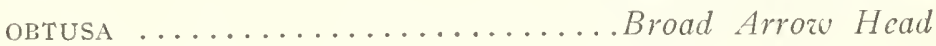

The genus remarkable for its variations in leaf and flower characters. Most of the fourteen named species cain be traced in our county, but they seem to be mere forms not varieties. The pollen is largely distributed by the glassy winged dragon fly.

\section{SABBATIA,}

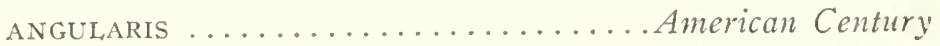

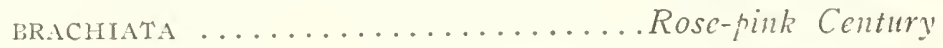




\section{SANICULA,}

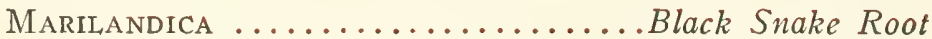

\section{SCROPHULARIA,}

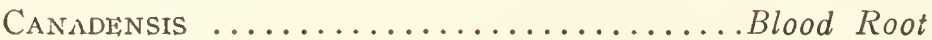

Showy but fragile flowers, common everywhere. The blossom attracts insects which gather pollen but no nectar. Named from the color of the juice.

\section{SAMOLUS,}

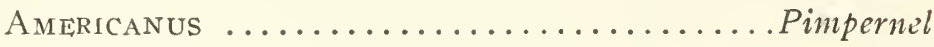

\section{SAXIFRAGA,}

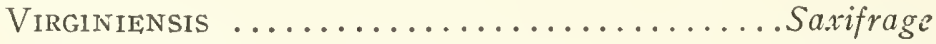

Pennsylvanica ...............................

SCROPULARIA,

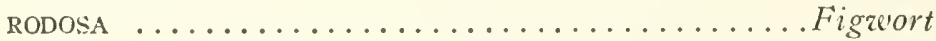

\section{SCUTELLARIA,}

LATERIFLORA $\ldots \ldots \ldots \ldots \ldots \ldots \ldots$ Skullcap

PrLosa .................................

VERSiCOLOR $\ldots \ldots \ldots \ldots \ldots \ldots \ldots$ Skullcap

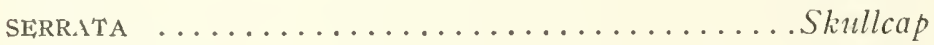

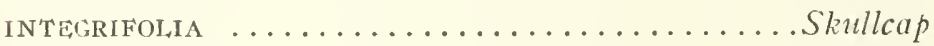

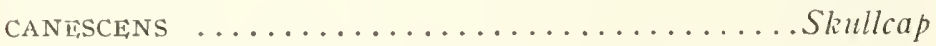

A quack doctor having formerly vaunted its virtues as a remedy for hydrophobia the genus bears the name of Mad-Dog-Skullcap. Flowers are fertilized by the bee Halictus and leaf cutter Megachile.

SENECIO,

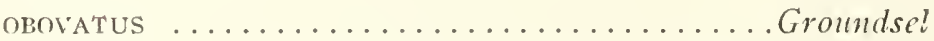

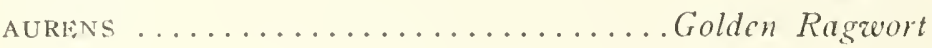



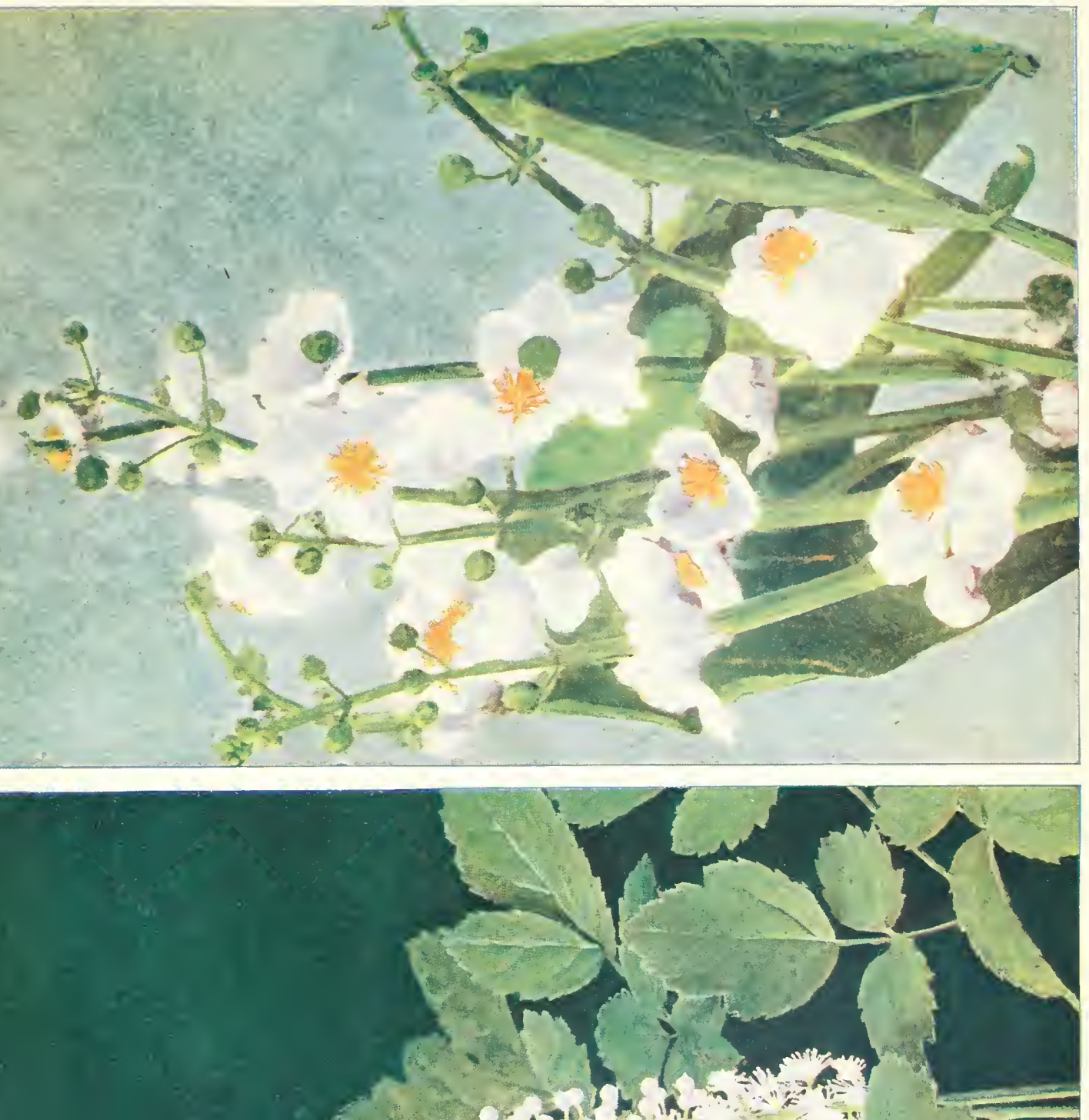
क्रो 



\section{SISYRINCHIUM,}

Bermudiana .....................eyed Grass

SILENE,

ROTUNDIFLORA ......................... Campion

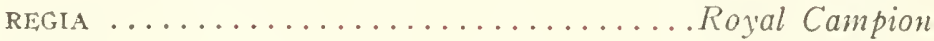

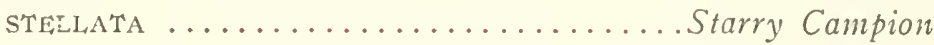

ALBA .................................. Campion

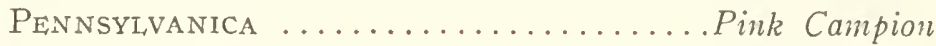

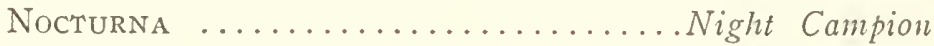

INFLATA $\ldots \ldots \ldots \ldots \ldots \ldots$. . . . . . . Campion

Beautiful but delicate flowers. Some open in sunshine and others at night, being visited by laige moths.

SIDA,

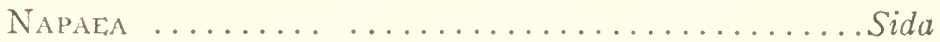

\section{SMILACINA,}

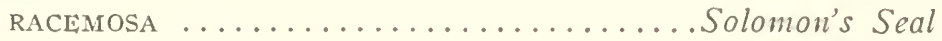

\section{SMILAX,}

ROTUNDIFOLIA ..............................

HERDACEA .............................. Flower

GLACCA $\ldots \ldots \ldots \ldots \ldots \ldots \ldots$ Sarsaparilla

\section{SOLIDAGO,}

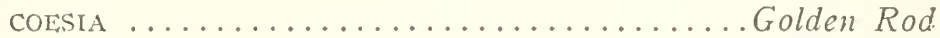

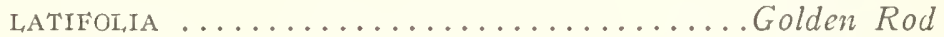

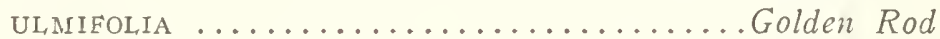

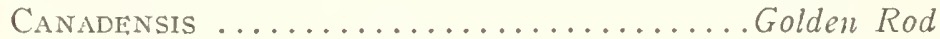

Some twenty species have been collected in this county, showing many forms of leaf and fower. Flowers are visited day and night by insects and there seems supply of pollen and nectar for all. 
SOLANUM,

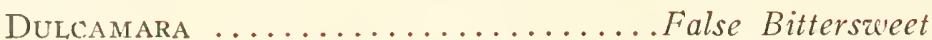

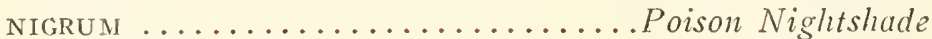

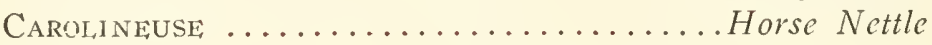

SPARGANUM,

SIMPLEX .......................... Reed

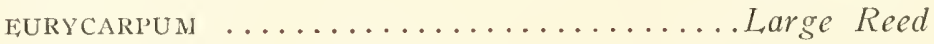

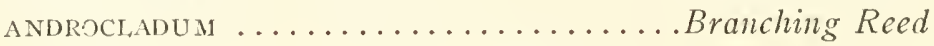

\section{SPECULARIA,}

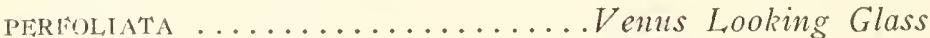

\section{SPIRANTHES-ORCHIS,}

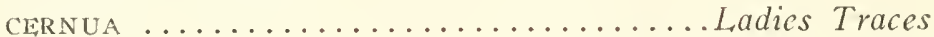

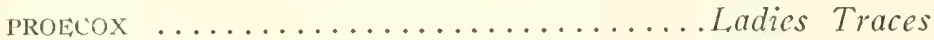

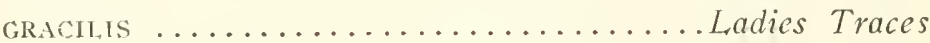

The name alludes to the spiral flower spike.

The odor of last named is peculiarly aromatic

reminiscent of the horse chestnut, but remarkably sweet, attracting many insects. The two inist abundant at I 200 feet above sea level, the lust in swamps.

\section{SPIROEA,}

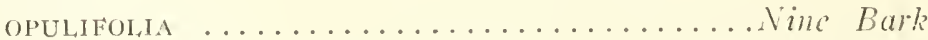

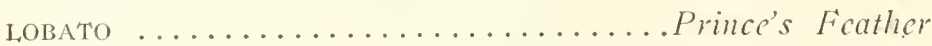

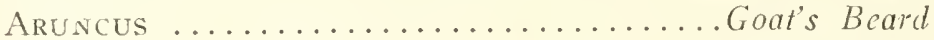

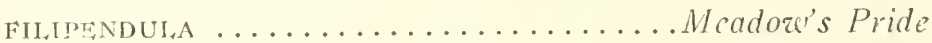

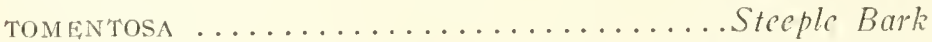

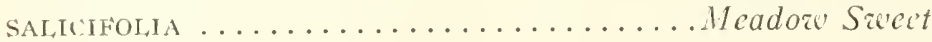

\section{STACHYS,}

ARVENSIS ..................Woundarer

ASPERA $\ldots \ldots \ldots \ldots \ldots \ldots \ldots$ Hedge Netti.

PAIUSTRIS .................. Hedge Nettle

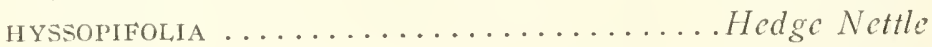

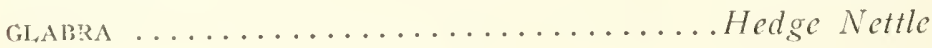



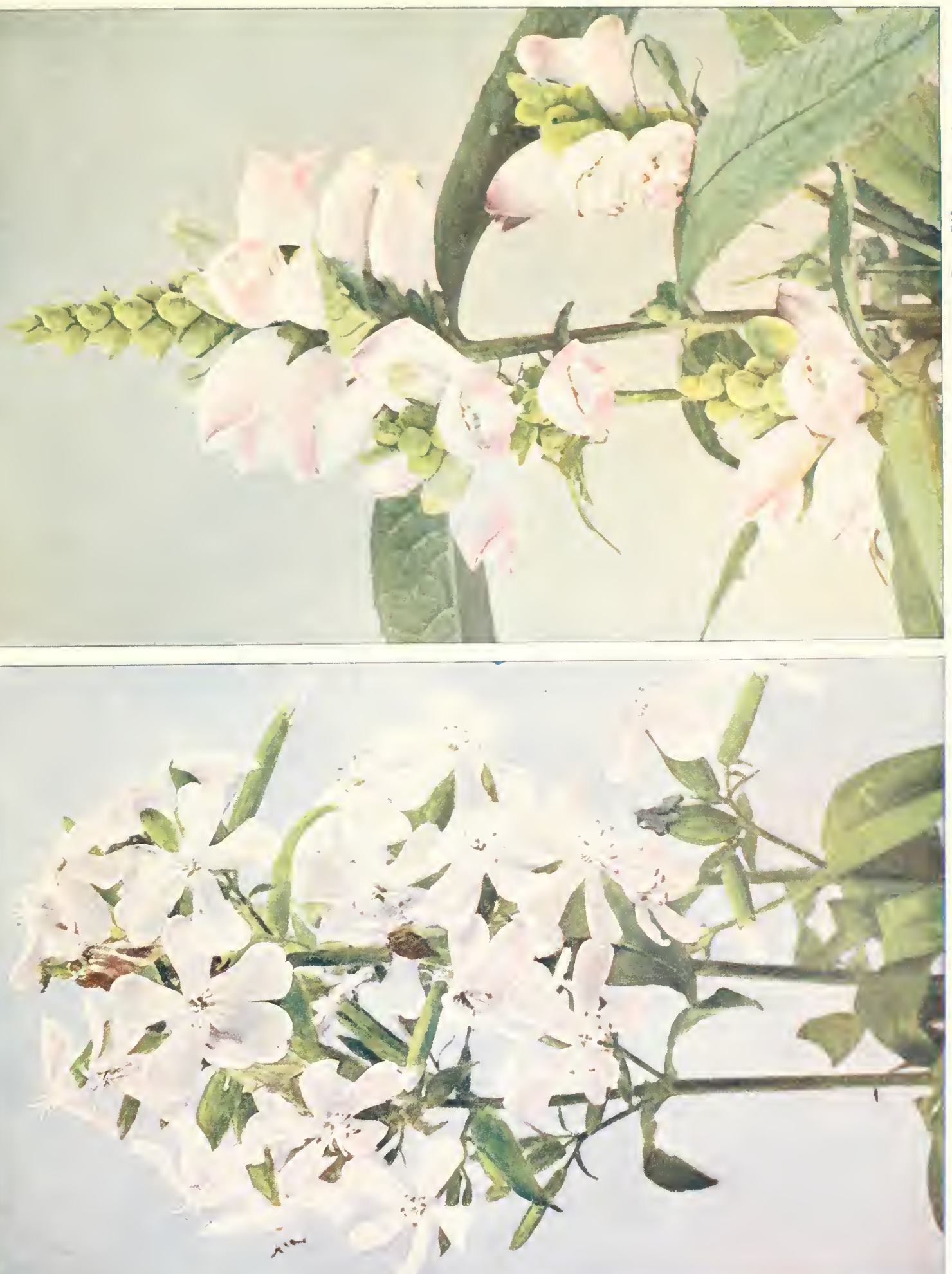



\section{STENANTHIUM,}

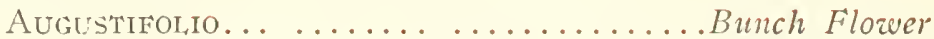

Cne of the most handsome and showy plants, with wand like leafy stem and conduplicate keeled leaves. Numerous flowers in compound racemes, waving like plumes in the wind. Spikes of flower heads often five to seven feet high. Flowers are polygamous, staminate, pistillate and perfect on same plant.

\section{STRUTHIOPTERIS,}

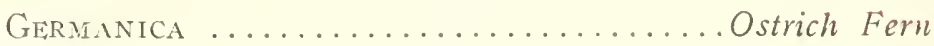

\section{STELLARIA,}

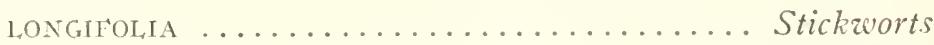

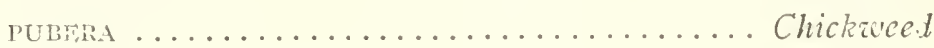

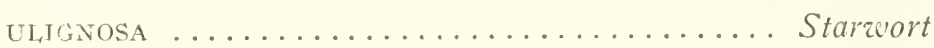

\section{SYMPLOCARPUS,}

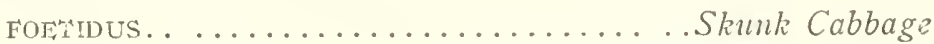

This plant really has no season of rest. Flower buds form in the fall as leaves drop away and are constantly pushing upwards so that in the first warm days of February they appear above ground and by St. Patrick's day they are in full bloom. It is the leader of the spring pageant of flowers and insects find them out by the fragrant smell they emit like unto old mustard piasters and onions. Honey bees, banded flies and millers patronize the flowers and often end their lives there, as spiders spin a web across the opening in spathe and leisurely feed on the prisoners. Later the leaves appear and form great tufted crowns. 
TARAXACUM,

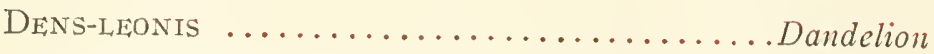

Under date of November 3oth, I902, H. S. NicCauley told the Physicians' Club that I00,000 children in Chicago did not know a ruse from a dandelion. After an investigation in three of the largest schools it was found tliat the charges were true. With children as old as fourteen years, "lilocks, daisies, lily buds" were the joyous cries shrilled forth when violets were exhibited. Largely in all the graded schools of Beaver county, nature studies are taught by displaying in school room windows plants, nests and mounted insects.

TANACETUM,

VULGARE $\ldots \ldots \ldots \ldots \ldots \ldots \ldots \ldots \ldots \ldots \ldots \ldots \ldots \ldots \ldots \ldots \ldots$

Introcluced into the county by Dr. Barney Dustan, at Darlington in ISI2. The doctor was the first physician in the county to abandon the barbarous and useless process of blecding. He was known as the "Botanical Doctor" and with tansy, celandine, wormworl and whiskey, oitained many marvelous cures.

\section{TEUCRIUM,}

Canadense $\ldots \ldots \ldots \ldots \ldots \ldots \ldots \ldots$ Germander

Sometimes called wond sage, the leaves being rich in a volatile oil. Named for Teucer, king of Troy. The lower lobe of flowers broad and furnishes a good landing for the Andrea ground bees, seeking the nectar and pollen. 


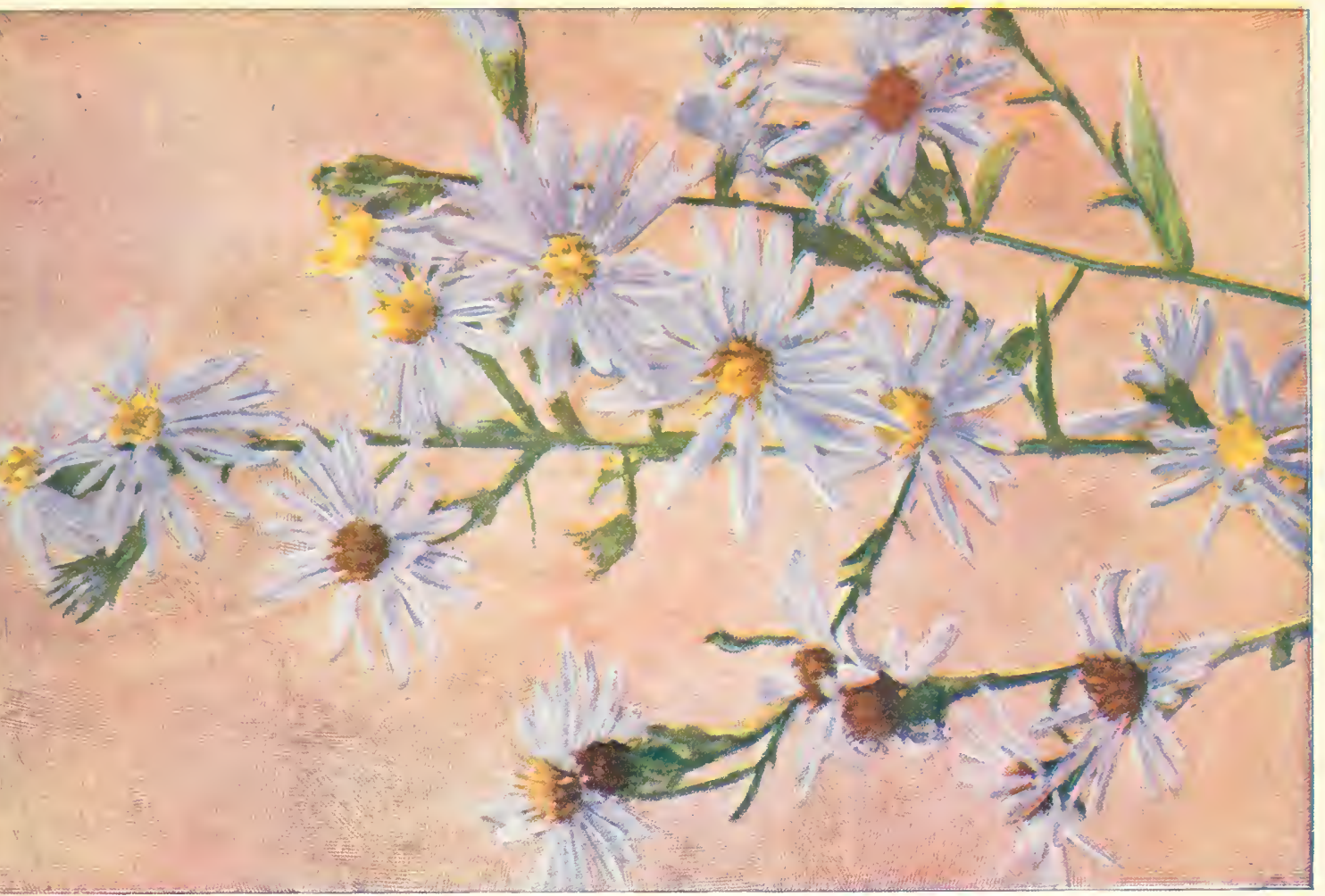

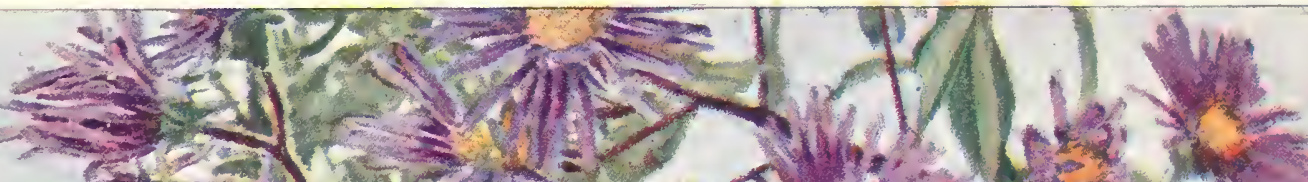

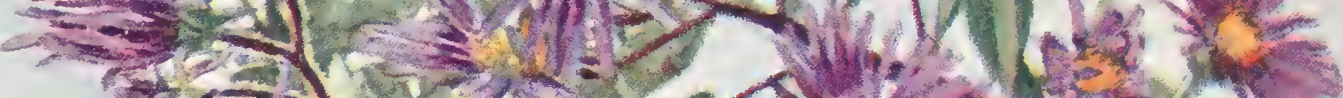

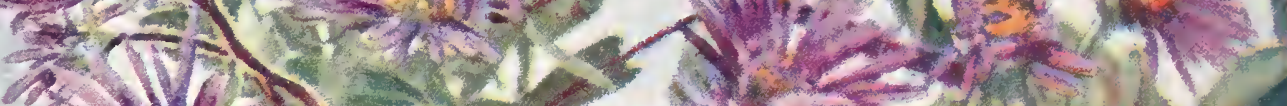

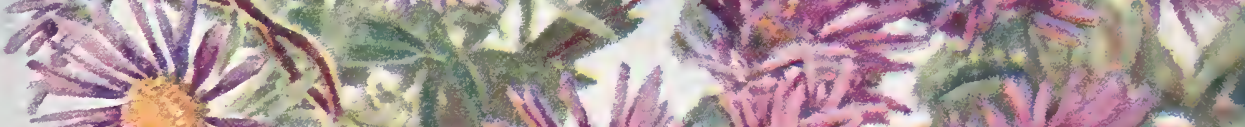

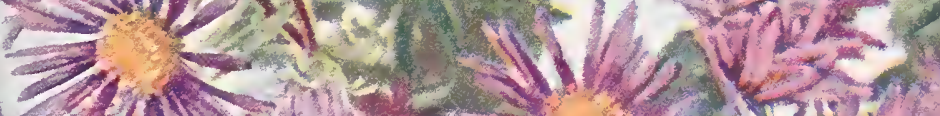

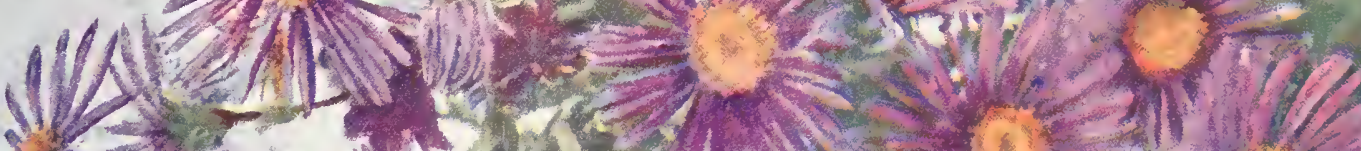

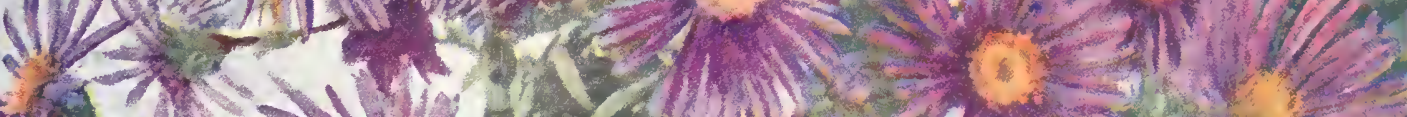

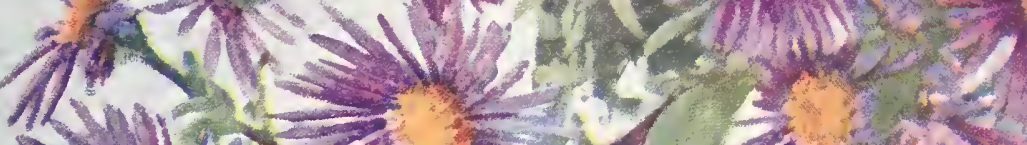

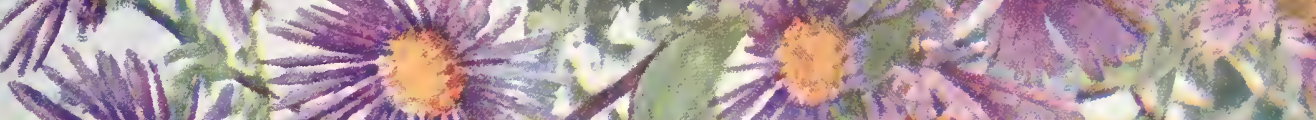

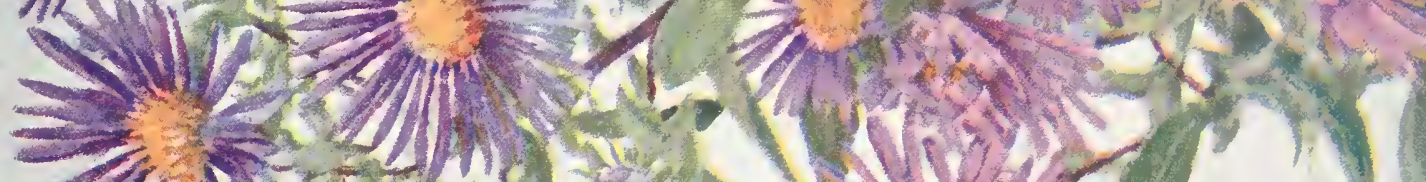

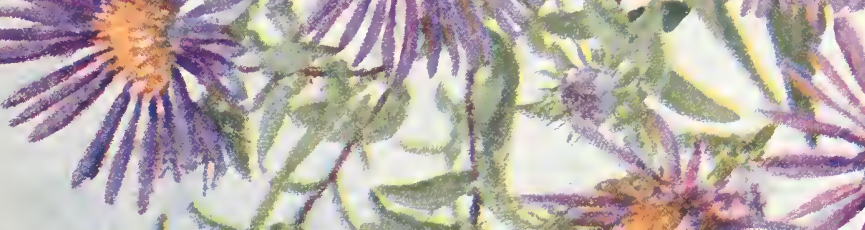

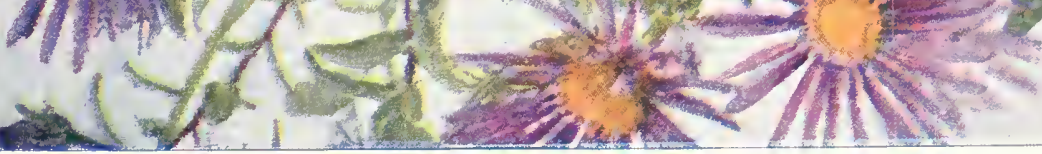





\section{TEPHROSIA,}

VirGtiniana ................................ Rut

Of the I25 species, only this one extends north into our county. The odd pinnate leaves are remarkable for their peculiar veins, not netted or brancling, but extending parallel to each other obliquely from the midrib. The red, purple and white flowers are conspicuously papilionaceous, with petals borne on claws. The plant is locally known from its long rootlets as the devil's shoestrings.

THALICTRUM,

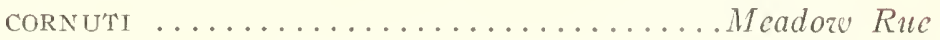
DIOICUM ...................Early' Rue

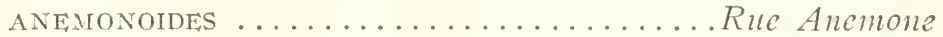
PURTURASCEUS .......................... Rue

Graceful, airy plants with plume clusters of misty white flowers. The several species all scem to be favorites with bees and butterflies though the flowers are polygamous.

\section{TRIFOLIUM,}

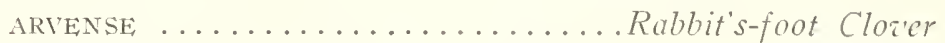

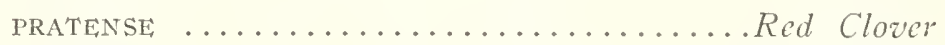
REFLEXUM ........................ffalo Cloz'er REPENS .................. White Clower

Pratense is the common red clover and dependent upon bumble bees for fertilization; arvense, with fuzzy heads is an emigrant from in riope; repens is rich in nectar and fertilized by the honey bee. Tradition makes it identical with the Shamrock of Ireland. 
TRADESCANTIA,

VIRGINICA ......................... Spiderwort

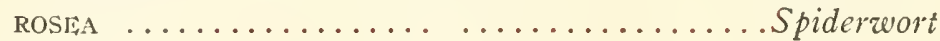

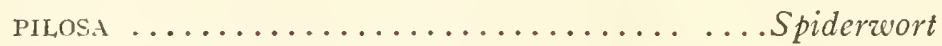

A genus of plants, showing variety in leaf and habit. They have been much improved by cultivation. Named for John Tradescant, a noted gardener to Charles I of England. Flowers visited by the Papillo butterflies and humming birds.

TRILLIUM,

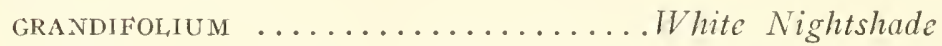

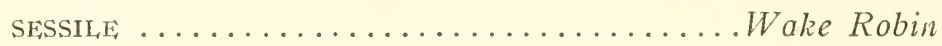

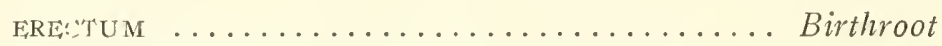

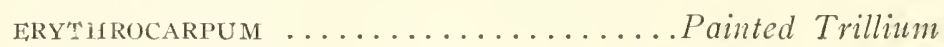

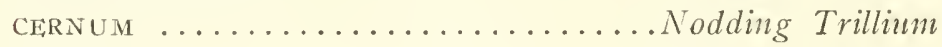

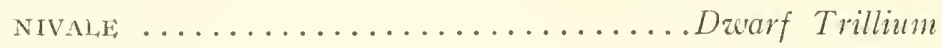

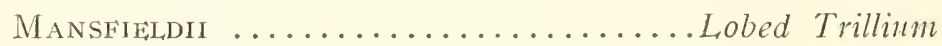

Several species have two and three stems from the same root, and some flowers are double, in which the various organs have reverted to leafy bracts, showing several whorls of pure white petals. Efforts have been made to discover our native plants and this genus has been called a "native," but about as much progress has been made as in the discovery of our native inhabitants. Adventurers, tourists and emigrants both of flowering plants and men, have settled in our county and become naturalized citizens, but we are forced to conclude that plants like men had one common origin. The last species was named by Prof. Lesquereux, showing each petal three lobed, like the livericaf. Variation in these species have been compared for many years, and they do not revert to the parent form, the tendency to variation is continuous. 


TRIENTALIS,

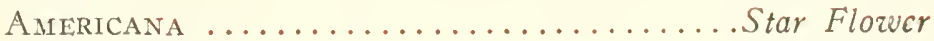

\section{TYPHA,}

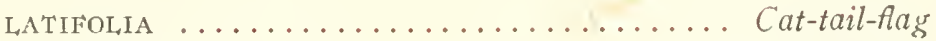

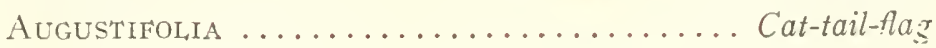

The upper half of the cylindrical spike consists of stamens only, the lower half are ovaries or pistils. The powdery pollen of the staminate flowers, scatters itself over the pistillate flowers below and thus fertilizes them. The leaves of this plant, with sedges and equisetams work up beautifully into raffia or basketry, the popular fad, with young ladies.

UNIOLA,

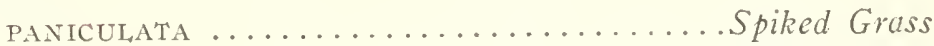

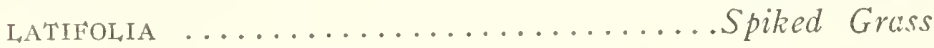

\section{UTRICULARIA,}

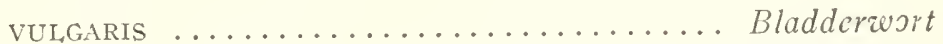

An interesting plant, having no home being blown from shore to shore by the winds. Botanists have been unable to decide whether the capillary dissected stems are leaves or rootlets. The flowers are pouched, having stomach like sacs, into which insects are entrapped.

URTICA,

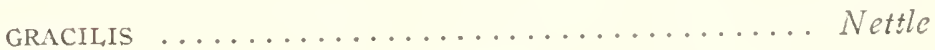

UVALARIA,

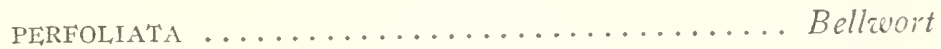

GRANDIFLORA $\ldots \ldots \ldots \ldots \ldots \ldots \ldots$ Bellwort

SHSSIFOLIA $\ldots \ldots \ldots \ldots \ldots \ldots \ldots \ldots$ Belliciort 


\section{VACCINUM,}

STAMINEUM .................... Squaw Huckleberry

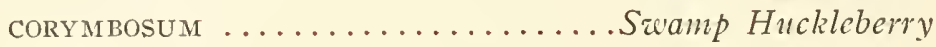

\section{VALERIANA,}

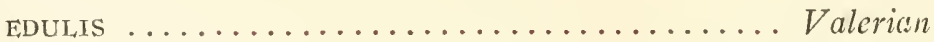

PAUCIFLORA $\ldots \ldots \ldots \ldots \ldots \ldots \ldots$ Valerian

\section{VERBASCUM,}

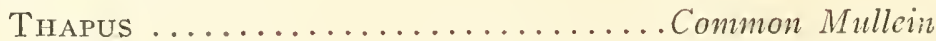

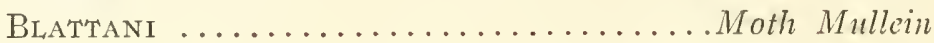

Lychnitis ....................White Mullein

Picturesque weeds with velvety leaves, that are prized in making liniment for strains. The last species is rare and hybridizes spontaneously with the first named.

\section{VERBENA,}

HASTATA .......................... Vervain

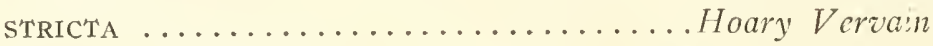

OFFICINALIS ................ European Veratin

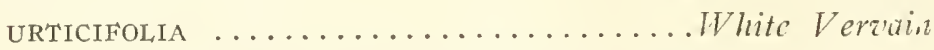

With its branches Roman priests swept the altar of Jupiter. In Gaul, the vervain was used in divination; also by the Druids. The botanist, Gerarde, says, "Manie old wives fables are written of holy vervaine gainst witchcraft made availing."

\section{VERONICA,}

ANAGALIS .................Water Speedré.

VIRGINICA ............................... Ruot

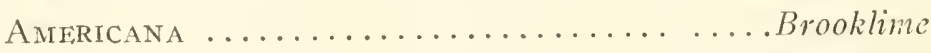

HEDERAEFOLIA .................. Speedrell 

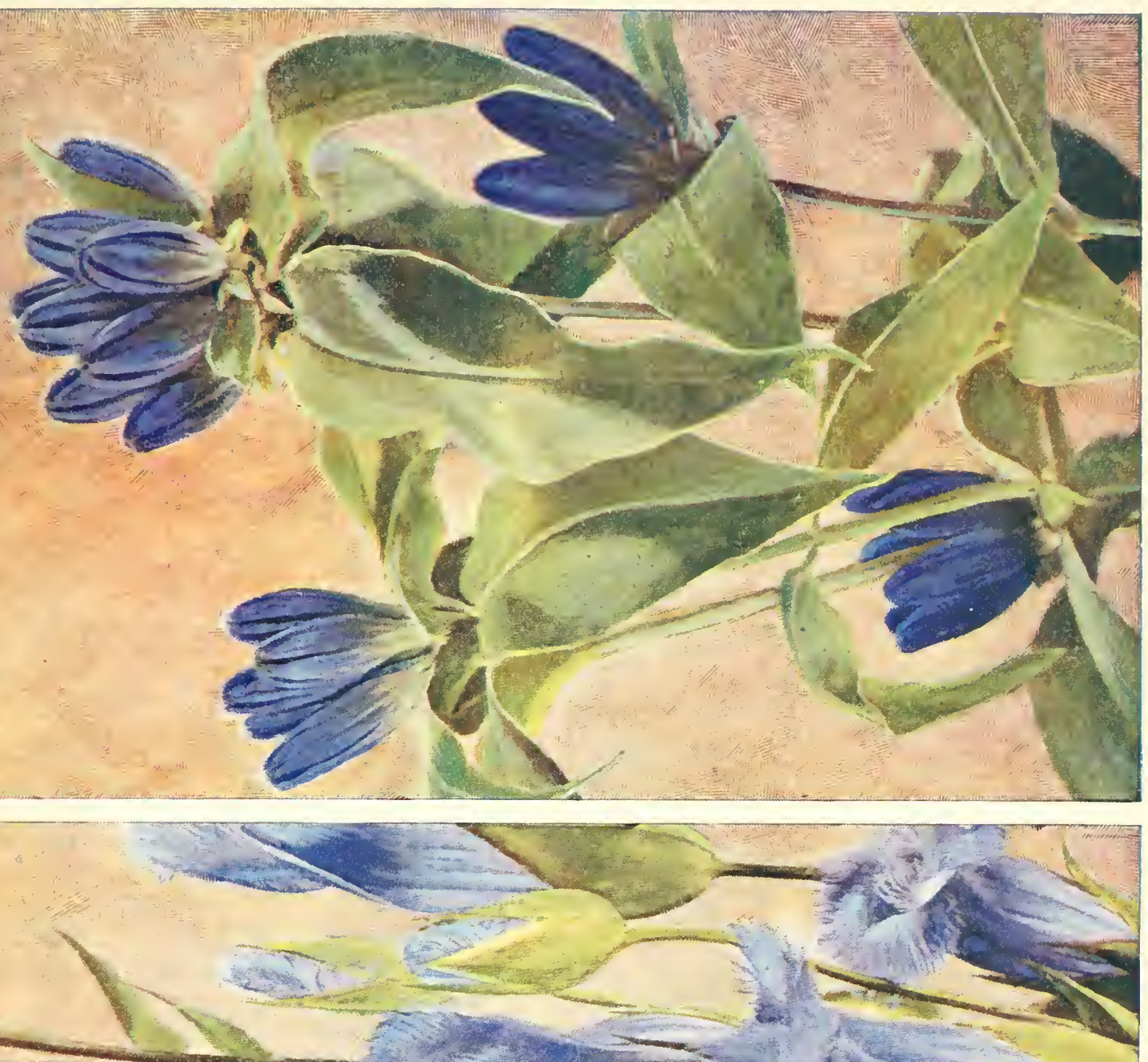

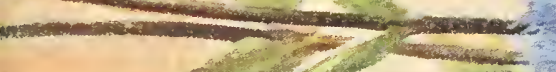

and

and

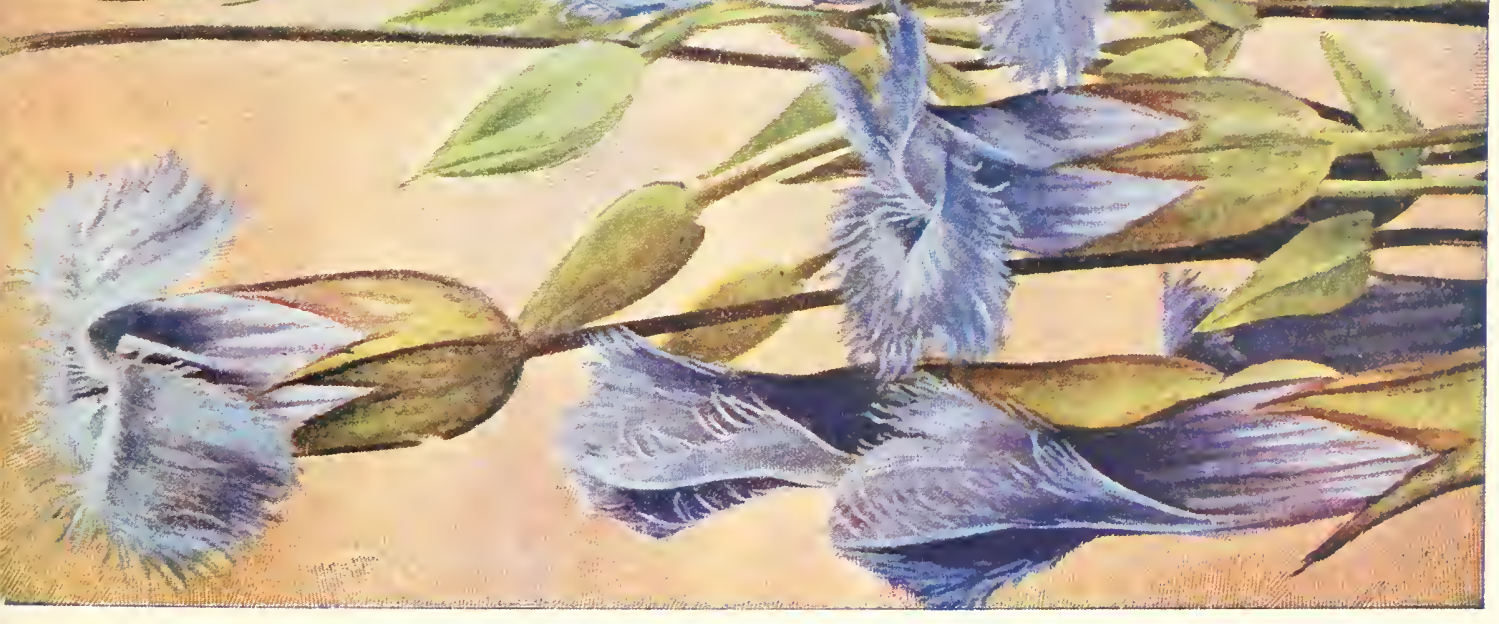



VERNONIA,

Notegorachissis ..................... Iron Weed

VICIA,

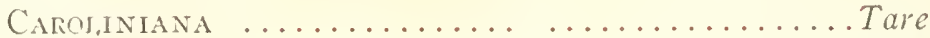

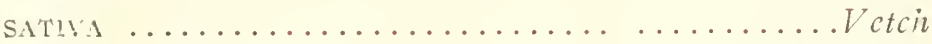

CRAcCA $\ldots \ldots \ldots \ldots \ldots \ldots$ Tufted Vetch

\section{VIOLA,}

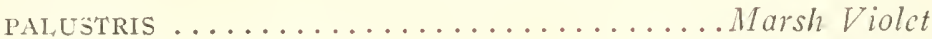

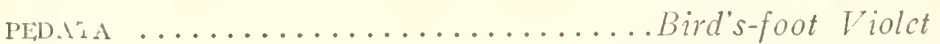

SAGITATA ....................trowleaz'd Violet

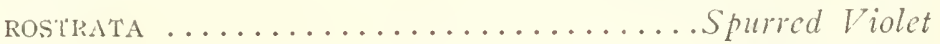

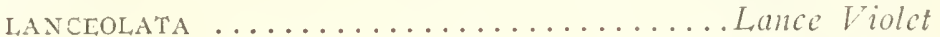

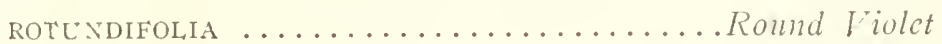

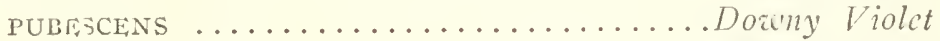

ERIOCARPA ...................W Woolly Violet

CANIDENSIS ............................. Vadalet

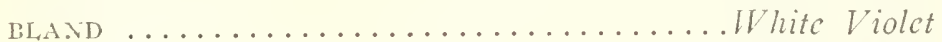

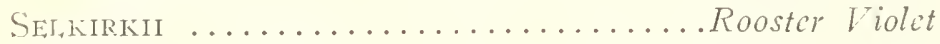

Several species have cleistoganous flowers :inder ground, their own pollen fertilizing their own ovules. Some of the flowers are so urregular as to require insect agency. Children take the spurred blossmms and fight until the other has lost its head, which gives the common name, "roosters."

WALDSTEINIA,

FRAGARIOIDES ......................... Strawberm

WOODSIA,

obTuSA .........................Rock Polypod

I'rof. Leo. Lesquereux, with Mr. Mansfield, spent several sears examining the fossil plants and ferns of Peaver county, and from those found in connection with Cannel Coals, decided the present fern flora partook of the character of the fossil flora, and that the evolutionary theory could not be accepted. 
XANTHIUM,

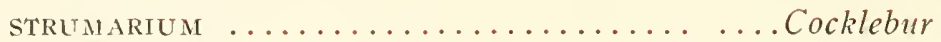

ECHINATUM $\ldots \ldots \ldots \ldots \ldots \ldots \ldots$ Cocklebur

XYLOSTEON,

CILITA ....................... Honeysuckle?

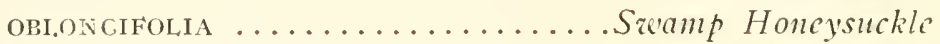

ZIZIA,

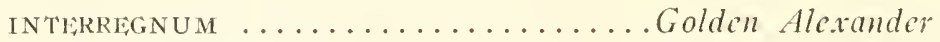

Mr. Andrew Carnegie startled our country by offering ten million dollars for the founding of a great university to be located at Washington, I. C., with the aim to promote original research and insure the publication of same. In the C'ctober issue of "The Plant World," published at Washington, they show by reliable authority that not one-half of the living flora is known to science, and nothing like a final attempt at classification can be made until all plants are known and illustrated.

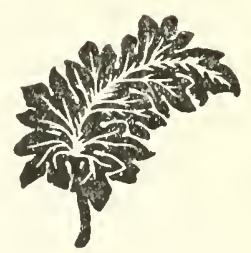







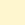


QK 131. M35

Mansfield, Ira Fran/Contributions to the

|| || || | | | || || || ||| || | | |

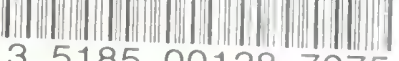

3 5185001287075 


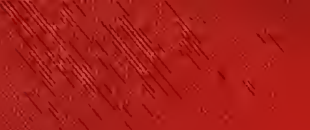

is

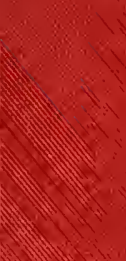

Mor

H.

Mon

in

2010

Nitis

in

$(x)$

$4 N^{*}+3$

(1)

iv

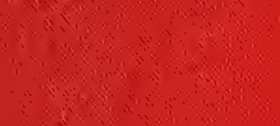

38

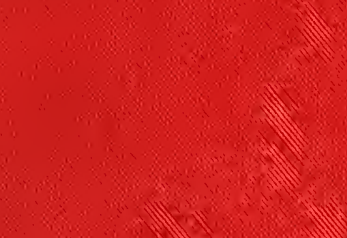

is

iiv.

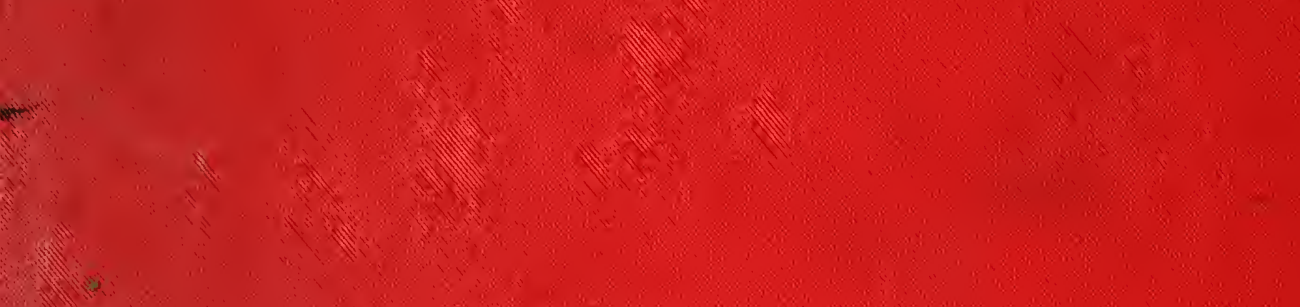

\&.

y

$$
\text { s a }
$$

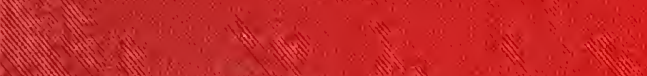

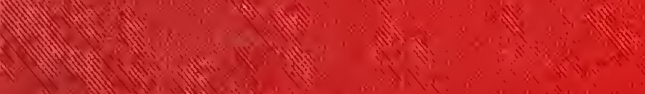

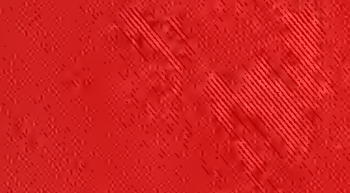

$+1$
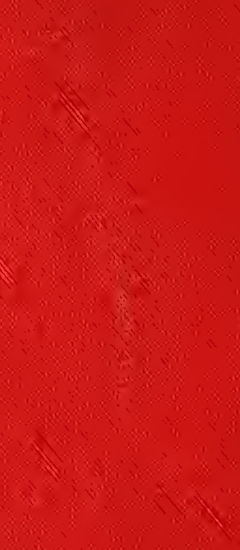